\title{
Molecular mechanism, diagnosis, and potential treatment for novel coronavirus (COVID-19): a current literature review and perspective
}

\author{
Yashwant Kumar Ratre ${ }^{1} \cdot$ Namrata Kahar $^{2} \cdot$ L. V. K. S. Bhaskar ${ }^{2} \cdot$ Antaripa Bhattacharya $^{3} \cdot$ Henu Kumar Verma $^{4}$ (D
}

Received: 3 October 2020 / Accepted: 12 January 2021 / Published online: 25 January 2021

(c) King Abdulaziz City for Science and Technology 2021

\begin{abstract}
Novel coronavirus disease 2019 (COVID-19) is a positive-sense single-stranded RNA virus which belongs to the Coronaviridae family. COVID-19 outbreak became evident after the severe acute respiratory syndrome coronavirus and the Middle East respiratory syndrome coronavirus in the twenty-first century as the start of the third deadly coronavirus. Currently, research is at an early stage, and the exact etiological dimensions of COVID-19 are unknown. Several candidate drugs and plasma therapy have been considered and evaluated for the treatment of severe COVID-19 patients. These include clinically available drugs such as chloroquine, hydroxychloroquine, and lopinavir/ritonavir. However, understanding the pathogenic mechanisms of this virus is critical for predicting interaction with humans. Based on recent evidence, we have summarized the current virus biology in terms of the possible understanding of the various pathophysiologies, molecular mechanisms, recent efficient diagnostics, and therapeutic approaches to control the disease. In addition, we briefly reviewed the biochemistry of leading candidates for novel therapies and their current status in clinical trials. As information from COVID-19 is evolving rapidly, this review will help the researcher to consider new insights and potential therapeutic approaches based on up-to-date knowledge. Finally, this review illustrates a list of alternative therapeutic solutions for a viral infection.
\end{abstract}

Keywords Coronavirus $\cdot$ COVID-19 $\cdot$ Diagnosis $\cdot$ Therapeutic $\cdot$ Molecular mechanism

Yashwant Kumar Ratre and Namrata Kahar are contributed equally to this work.

Henu Kumar Verma

henu.verma@yahoo.com; henu.verma@ieos.cnr.it

Yashwant Kumar Ratre

yashwntratre@gmail.com

Namrata Kahar

namratakahar3@gmail.com

L. V. K. S. Bhaskar

lvksbhaskar@gmail.com

Antaripa Bhattacharya

antaripa1210@gmail.com

1 Department of Biotechnology, Guru Ghasidas Vishwavidyalaya, Bilaspur, India

2 Department of Zoology, Guru Ghasidas Vishwavidyalaya, Bilaspur, India

3 Department of Molecular Medicine and Medical Biotechnology, University of Naples "Federico II", Naples, Italy

4 Developmental and Stem Cell Biology Lab, Institute of Experimental Endocrinology and Oncology CNR, Naples, Italy

$\begin{array}{ll}\text { Abbreviations } \\ \text { CoVs } & \text { Coronaviruses } \\ \text { HCoVs } & \text { Human coronaviruses } \\ \text { SARS-CoV } & \text { Severe acute respiratory syndrome } \\ \text { MERS-CoV } & \text { Middle East Respiratory Syndrome } \\ \text { ORFs } & \text { Open reading frames } \\ \text { ACE2 } & \text { Angiotensin-converting enzyme 2 } \\ \text { APCs } & \text { Antigen-presenting cells } \\ \text { TH1 } & \text { T-helper } \\ \text { ER } & \text { Endoplasmic reticulum } \\ \text { HLA } & \text { Human leukocyte antigen } \\ \text { MBL } & \text { Mannose-binding lectin } \\ \text { ARDS } & \text { Acute respiratory distress syndrome } \\ \text { PRRS } & \text { Porcine reproductive and respiratory } \\ & \text { syndrome } \\ \text { ESR } & \text { Erythrocyte sedimentation } \\ \text { CRP } & \text { C-reactive protein } \\ \text { PCR } & \text { Polymerase chain } \\ \text { RT-PCR } & \text { Real-time reverse transcription PCR } \\ \text { HRCT } & \text { High-resolution computed tomography } \\ \text { ELISA } & \text { scans } \\ \text { LAMP } & \text { Lnzyme-linked immunosorbent assay } \\ & \end{array}$

\section{Abbreviations}

$\mathrm{CoVs}$

Human coronaviruses

SARS-CoV Severe acute respiratory syndrome

MERS-CoV Middle East Respiratory Syndrome

ORFs

Open reading frames

Antigen-presenting cells

T-helper

Endoplasmic reticulum

Human leukocyte antigen

Mannose-binding lectin

MBL

Acute respiratory distress syndrome

Porcine reproductive and respiratory

syndrome

ESR

Erythrocyte sedimentation

C-reactive protein

Polymerase chain

RT-PCR Real-time reverse transcription PCR

High-resolution computed tomography

Loop-mediated isothermal amplification 
RdRp CCRAS

RNA-dependent RNA polymerase

Central Council for Ayurvedic Sciences

Research evolving rapidly, this review may help researchers accurately understand disease.

\section{Introduction}

A pneumonia outbreak with uncertain etiology occurred in Wuhan, Province of Hubei, in the last week of December 2019 is severely impending for human health worldwide (Li et al. 2020b). Later on January 7, 2020, the Chinese administration announced the naming of a new form of coronavirus-2 (SARS-CoV-2) that belongs to the Coronaviridae family (Xiao et al. 2020). It is noteworthy that SARSCoV-2 is $96 \%$ genetically similar to a bat coronavirus at the whole genome level (Zhou et al. 2020). Coronavirus disease (COVID-19) is an extreme acute respiratory syndrome with the most common symptoms of moderate infection include fever, dry cough, tiredness, sore throat or dyspnea. Patients infected with this virus suffer from other potential damage to vital organs, such as gastrointestinal, cardiac, renal, and nervous systems (Gavriatopoulou et al. 2020; Merad and Martin 2020; Rohollah et al. 2020; Bhaskar et al. 2020). Recent knowledge indicated that the SARS-CoV-2 transmission rate is higher than SRAS-CoV due to the protein structure's genetic makeup. Before COVID-19, many infectious diseases affected global populations, including plague, Spanish flu, cholera, Swine flu (H1N1), severe acute respiratory syndrome coronavirus (SARS-CoV) and Middle East respiratory syndrome coronavirus (MERS-CoV) (Bramanti et al. 2019; Taubenberger and Morens 2006; Chowdhury et al. 2017; Ratre et al. 2020; Luk et al. 2019).

Till now, there are no effective vaccines available to prevent the spread of COVID-19 although many clinical trials of vaccines are underway (Verma et al. 2020b). SARSCoV-2 has now spread to more than 205 other nations, including the United States, India, Russia, Brazil, Italy, Spain, Japan, Korea, Iran and Germany. In March, the WHO announced that COVID-19 was a pandemic and a significant health issue, causing severe infections in the respiratory tract (Cucinotta and Vanelli 2020; Mahase 2020). According to the latest statistics, more than 50 million people have been infected worldwide up to 10 December 2020, and more than $10,35,000$ were died because of this disease. Every day, the number of infected people are growing worldwide. India has $95,53,100$ cases registered to date. Fortunately, the death rate is very low in youngsters. As COVID-19 is a novel infectious disease, scientists and doctors are not much aware of it. In this critical circumstance, in-depth knowledge is highly essential for the future treatment and management of the disease. In this review, we summarized the pathophysiology, molecular mechanism, diagnosis, and possible therapeutic options for this disease. Because knowledge of COVID-19 is

\section{Pathophysiology of COVID-19}

Coronaviruses (CoVs) are non-segmented nucleocapsid-protein enveloped + SS-RNA viruses that are known to cause infection in mammals, including humans and other host species (Pal et al. 2020). Genomic studies have revealed that the CoVs has the most abundant RNA genome of around $30-30 \mathrm{~kb}$ in length with a 5'-capping site and 3'poly-A tail region that promotes host genome transcription and translation. Based on the genomic structure and target host, this virus is generally categorized into four groups, including alpha, beta, gamma, and delta. Among these forms, only alpha and beta forms of viruses known to infect mammals and typically cause upper respiratory infections (Rabi et al. 2020). Seven human coronaviruses (HCoVs) have been identified to date, such as 229E, OC43, HKU1, NL63, SARS-CoV, MERS-CoV, and SARS-CoV-2 was identified as belonging to the beta coronavirus family.

In the host genome, the pathogenic in vivo appearance of SARS-CoVs falls in different stages. The binding of the virus to the host receptors, entry of the virus into the host cells by membrane fusion or endocytosis, the release of virus particles within the host cell followed by replication and biosynthesis of viral proteins, and budding/release of viral particles are sequential steps. According to the virologists, the pathophysiology and virulence mechanism of human SARS-CoV and SARS-CoV-2 are possibly similar $(82 \%$ identical) to the work of non-structural proteins (nsps) and structural proteins (sps) (Chan et al. 2020a). To date, the coronavirus genome has recorded six open reading frames (ORFs), these ORFs can serve as a template for the biosynthesis of subgenomic mRNAs. Among these, ORF1a and ORF1b encode 16 nsps that are typically crucial for virus transcription and replication. Other ORFs encode four major sps: spike (S), membrane (M), envelope (E) and nucleocapsid (N), and other vital proteins (Snijder et al. 2003; Luk et al. 2019). Spike a glycoprotein surface consists of two structural components $\mathrm{S} 1$ and $\mathrm{S} 2$. Among them, S1 binds to the angiotensin-converting enzyme 2 (ACE2) receptor that highly expressed in the host genome's lung epithelial cells. S2 also contains a transmembrane domain, cytoplasmic domain, and fusion protein that facilitates virus fusion in the envelope and host cell membranes to enable viral fusion. Scientists are, therefore looking S2 as a promising target for antiviral drug therapy (Kirchdoerfer et al. 2016; Xu et al. 2020a). Zhou et al. (2020) recently reported that the novel SARS-CoV-2 could also identify ACE-2 receptors in human cells. 
Unlike other coronaviruses, the SARS-CoV-2 has a unique furin cleavage site at the S1/S2 boundary ("RPPA" sequence) that makes this virus pathogenic. Other cell surface proteases such as transmembrane protease serine 2 (TMPRSS2) and cathepsin L also facilitate the cleavage of the complex S1/S2-ACE2 and help to activate viral spike proteins for entry into the host genome (Ou et al. 2020; Hoffmann et al. 2020). In pathogenesis, the envelope proteins play an essential role by facilitating the assembly and release of coronavirus. The N-terminal N-protein binds to the single positive RNA genome and plays a crucial role in the replication and transcription cycle. Currently, two groups of antiviral drugs, such as theophylline and pyrimidone, may inhibit the binding of viral RNA to N-terminal protein (Sarma et al. 2020).

When the virus reaches the body, the host's immune system it activates a sequence of inflammatory events triggered by antigen-presenting cells (APCs). APCs add foreign antigen to cells containing CD4+-T-helper (TH1) and release interleukin-12 to activate TH1. Besides, the activated TH1 cells trigger CD8+-T-killer cells which recognise and eliminate infected host cells. TH1 cells also activate B-cells to synthesize viral-specific antibody that is unique to viruses. The infection spreads in the mucosa of the nasal and larynx, then targets lung epithelial cells, which express ACE2 receptors in abundance (Chen et al. 2020a; Bennardo et al. 2020). Activated WBCs activate positive cytokines, including IL-6. However, the IL-6 level elevates in the extreme state of the disease, which raises the aggressiveness of coronavirus.

\section{Molecular mechanism of COVID-19}

Coronaviruses are ubiquitous pathogens that cause respiratory or gastrointestinal infections. A recent phylogenetic analysis found that 2015-SARS coronavirus sequence and human 2019-SARS-CoV-2 emerged in the congregation of a bat. In addition, the Bayesian Quick Unconstrained AppRoximation (FUBAR) analysis revealed genomic mutations in the viral $\mathrm{S}$ glycoprotein and nucleocapsid protein (Benvenuto et al. 2020). Compared to the ability of infection with coronaviruses, SARS-CoV-2 has a higher binding affinity to human ACE2 than SARS-CoV, which may explain the frequency of SARS-CoV-2 than SARS-CoV (He et al. 2020). Diverse work has shown that this link between SARS-coronavirus and ACE2 enables a smooth entry into human cells (Struck et al. 2012). Unlike non-ACE2 expressing cells in the ACE2-expressing cells, the novel SARS-CoV-2 uses ACE2 after binding to infected host cells as an entry receptor. Chemokine ligand 2 (CCL2) is the small chemical molecules that attract immune cells including lymphocytes, basophils, and monocytes. This also penetrated the various inflammatory reactions and in the S-ACE2 signaling (Hoffmann et al. 2020), and serves as a critical cytokine. Cheung et al. confirmed the increased expression of chemotactic protein CCL2/monocyte 1 in patients with SARS-CoV and hence CCL2 can be a promising therapeutic marker (Cheung et al. 2005).

Heurich et al. found that infected lung epithelial cells facilitate casein kinase II (CK II) which induces phosphorylation of the ACE2 receptor at the Ser-787 site, whereby SARS-CoV recognises and binds to the ACE2 receptor leading to a structural change of the ACE2 receptor. It also involved the establishment of ACE2 induced downstream signal transduction pathways, including ERK1/2 and AP1(Heurich et al. 2014). Simmons and colleagues reported that the SARS-CoV accomplishes its entry into host cells via membrane fusion between the virus and lipid bilayer (Simmons et al. 2004). Another finding from Belouzard et al. revealed that the occurrence of a crucial proteolytic cleavage on the $\mathrm{S}$ protein of SARS-CoV at $\mathrm{S} 2$ position mediates the membrane fusion involving host and $\mathrm{CoV}$ pathogen (Belouzard et al. 2009). Besides CoV, the MERS-CoV required furin activation for membrane fusion (Millet and Whittaker 2014). In addition to membrane fusion, clathrin-dependent and independent endocytosis has been reported to be mediated by the SARS-CoV entry (Kuba et al. 2010). Once the virus enters the host, eventually, the viral RNA releases into the cytoplasm.

Further, it translates itself into two polyproteins and structural proteins followed by replication of the viral genome (Perlman and Netland 2009) Later, the newly formed envelope glycoproteins enter the cell organelles naming the endoplasmic reticulum (ER) or Golgi complex. The nucleocapsid contains the mixing of genomic RNA and capsid protein. Then the virus buds are sprout into the ER-Golgi intermediate compartment. Lastly, the vesicles containing the virus particles blend with the plasma membrane to discharge the virus (de Wit et al. 2016). Details related to this is graphically presented in Figs. 1 and 2.

Additionally, it has been reported that the SARS-CoV is involved in the antigen-dependent presentation of MHC I molecules, but MHC II also contributes to its presentation (Liu et al. 2010). Want et al., conducted a polymorphism-based study and found that the human leukocyte antigen (HLA) polymorphisms such as HLA-B*4601, HLA$\mathrm{B} * 0703, \mathrm{HLA}-\mathrm{DR} \mathrm{B} 1 * 1202$, and HLA CW*0801 are associated with the susceptibility of SARS-CoV (Keicho et al. 2009). In comparison, they found that the HLA-DR0301, HLA-Cw1502, and HLA-A*0201 play a vital role in SARS infection and functioning as protective alleles (Wang et al. 2011). It has also been observed that mannose-binding lectin (MBL) gene polymorphisms are associated with antigen presentation and thus linked to the risk of infection with SARS-CoV (Tu et al. 2015). 
Fig. 1 Structure of SARS-CoV 2 (Modified from Shereen et al. 2020)

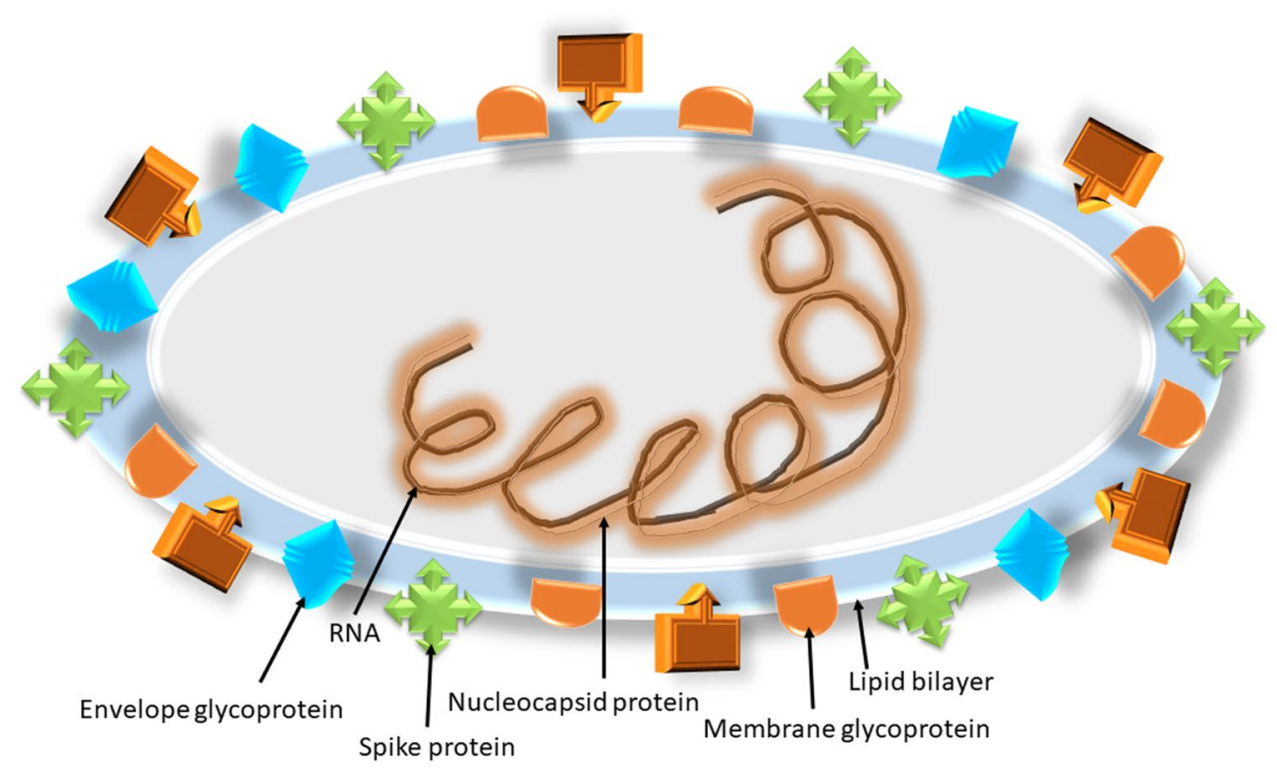

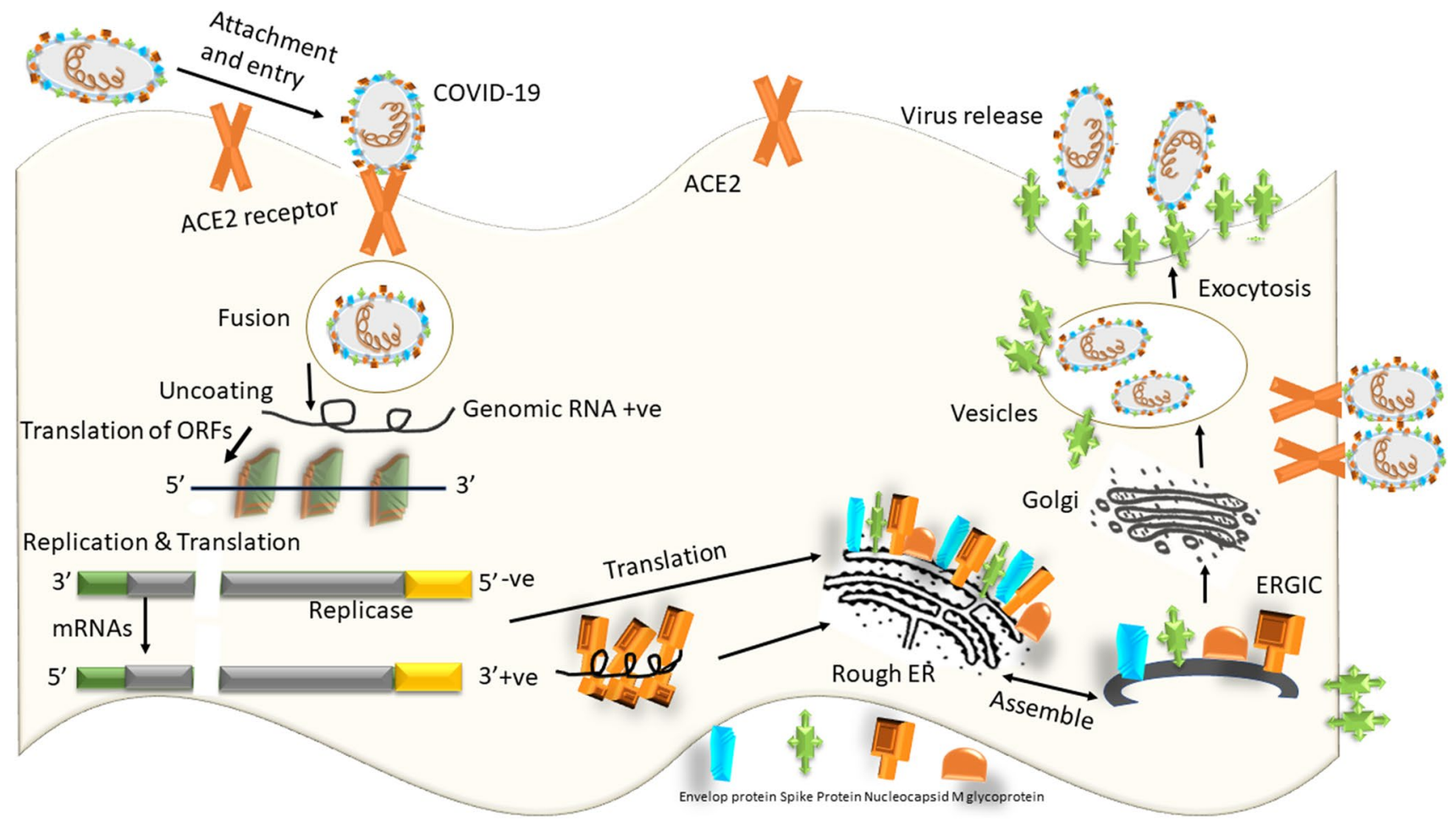

Fig. 2 Life cycle and mechanism of infection of SARS-CoV 2 in host cells. SARS-CoV 2 begins its life cycle when spike protein (S) binds to the cellular receptor ACE2. After receptor binding, the conformation change in the $S$ protein facilitates viral envelope fusion with the cell membrane through the endosomal pathway. Then SARS-CoV 2 releases RNA. Genome RNA gets translated into viral replicase polyproteins (pp1a and 1ab) and further cleaved into small prod- ucts by viral proteinases. The polymerase generates a series of subgenomic mRNAs by discontinuous transcription and finally translated into appropriate viral proteins. Viral proteins and genome RNA are subsequently assembled into virions in the ER and Golgi body and then transported via vesicles and released out of the cell. ACE2 Angiotensin-converting enzyme 2, ER Endoplasmic reticulum, ERGIC ER-Golgi intermediate compartment 
Research has indicated that acute respiratory distress syndrome (ARDS) is the leading cause of death in COVID-19 and one of the main routes for the cytokine storm associated with ARDS. Nevertheless, lethal systemic inflammatory response leading to elevated levels of pro-inflammatory cytokines such as IFN- $\alpha$, IFN- $\alpha$, TNF- $\alpha$, TGF $\beta$, IL- $1 \beta$, IL-6, IL-12, IL-18, IL-33 and chemokines such as CCL2, CCL3, CCL5, CXCL8, CXCL9, CXCL10 (Williams and Chambers 2014; Channappanavar and Perlman 2017). Xu et al. recently reported that the peripheral blood of SARS-CoV-2 patients displayed a substantial reduction in immune defence cells such as CD4+ and CD8+ T cells. In contrast, high concentrations of HLA-DR (CD4 3.47\%) and CD38 (CD8 $39.4 \%$ ) were also found in double-positive fractions within the same patients (Xu et al. 2020b). SARS-CoV viruses are adequate to employ many methods to prevent the survival of the immune system in host cells. Snijder et al. reported that SARS-CoV and MERS-CoV could provoke the assemblage of membrane vesicles that require for Porcine reproductive and respiratory syndrome (PRRS) and avoiding the host detection of their dsRNA (Snijder et al. 2006). These findings are valuable for the effective treatment of COVID-19.

\section{Diagnostic approach}

Many COVID-19 cases have moderate or non-specific symptoms for a correct diagnosis, while severe patients have respiratory problems, including fever, cough, tiredness, and shortness of breath, and decreased or diminished vocal fremitus on palpation (Xie et al. 2020a). Patient screening for precise diagnosis must be comfortable, low cost, quick, and the most reliable result. Studies into epidemiological history, clinical findings, and tests are essential for the clinical diagnosis of COVID-19. Imaging will be the first diagnosis. Suspected patients will undergo chest X-ray as soon as possible and an urgent CT scan based on severity (Shen et al. 2020a). The image can provide a better understanding of how the disease is progressing. Chest images may show interstitial changes in the preliminary process, and the presence of small plaques, especially in the lung periphery. This disease further deteriorates bilaterally and is primarily distributed with several infiltrative shadows in the middle and outer zones of the lung. In extreme cases, consolidation of the lung may occur (Pan et al. 2020b).

\section{Laboratory assessment}

In the early stage, the count of white blood cells generally appears normal or slightly low, with a smaller count of lymphocytes. But if the absolute count of lymphocytes is $<0.8 / \mathrm{L}$ or the counts of CD4+ and CD8+ T-cells are significantly decreased, this is a warning. But if the absolute lymphocyte count is $<0.8 \times 10^{9} / \mathrm{L}$ or the CD4+ and CD $8+$ T-cell counts are decreases substantially, that's an alarm. In some patients, muscle enzymes, liver enzymes, and levels of myohemoglobin are elevated; in some critical cases, even an increased amount of troponin is observed. Infected patients mostly show high erythrocyte sedimentation (ESR) and C-reactive protein (CRP) levels, with normal procalcitonin levels and progressively decreased blood lymphocyte counts with elevated D-dimer concentrations. In severe patients, inflammatory factors are also increased. It is recommended that blood changes be rechecked every 3 days (Jin et al. 2020).

Detection methods based on nucleic acid are an essential tool for the diagnosis of viral agents. In particular, the polymerase chain reaction (PCR) is a "gold standard method" for virus detection due to rapid identification, high sensitivity and specificity. Molecular diagnosis methods like realtime PCR (RT-PCR) can be executed using blood, feces, and tissue samples of the upper part of the respiratory tract (nasopharyngeal and oropharyngeal), lower respiratory tract (expectorated sputum, endotracheal aspirate, or bronchoalveolar lavage) from suspected patients with SARS-CoV-2 (Yu et al. 2020a). However, Nucleic acid detection has some drawbacks in its operation, such as the time-consuming and high risk of contamination. Nonetheless, current PCR methods appear to have functional specificity except for sensitivity, which means that negative test results did not guarantee that SARS-CoV-2 was absent. In addition, false-positive results may occur due to sample contamination, or false negative results may appear due to inadequate viral load. For people with high clinical suspicion but negative RT-PCR screening, chest $\mathrm{CT}$ can assist with clinical diagnosis.

A combination of CT scanning and swab examination appears to be more helpful (Xie et al. 2020b). Early detection and development of disease in patients with SARSCoV-2 can be done with high-resolution computed tomography scans (HRCT) (Pan et al. 2020a). The CT images of patients with SARS-CoV and MERS-CoV indicate lung involvement close to SARS-CoV-2 infection; besides, HRCT scans have certain drawbacks, including other virus infections and irregular CT imaging. RT-PCR experiments can be used with the chest CT scan in combinations to boost falsepositive outcomes (Chen et al. 2020b; Jiang et al. 2020). Although the detection of $\operatorname{IgM}$ and $\mathrm{IgG}$ antibody detection is highly responsive to enzyme-linked immunosorbent assay (ELISA) (Jia et al. 2020). A study found that $94.7 \%$ of SARS-CoV N-based IgG ELISA and $58.9 \%$ of S-based IgG ELISA and SARS-CoV-2 IgG/IgM are still being studied (Li et al. 2020a).

The Loop-mediated isothermal amplification (LAMP) is a novel method of amplification of DNAs and RNAs that enhances product with high sensitivity and specificity. The key benefits of this approach are low cost and less costly reagents and involving simple instruments (Shen et al. 2020b).

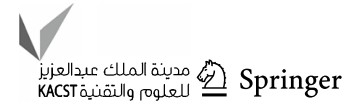


Recently Mohamed et al. demonstrated that the LAMP methods have 10 times more sensitivity than traditional RTPCR in COVID-19 detection without false-negative events (Mohamed et al. 2020). The iLACO (isothermal LAMP based method for COVID-19)uses 6 primers for amplifying the ORF1ab gene sequences of 11 associated viruses. Yu et al. compared both methods and found that the iLACO sensitivity and accuracy are higher than the Taqman-based qPCR detection method (Yu et al. 2020b). Zhang et al. also stated that LAMP with a colorimetric detection method has a high sensitivity to COVID-19 and that these methods can be used in the diagnosis for the bulk (Zhang et al. 2020b). Comparison of three novel RT-PCR assays targeting RNAdependent RNA polymerase (RdRp)/helicase (Hel), spike $(\mathrm{S})$, and COVID-19 nucleocapside $(\mathrm{N})$ genes showed that the RdRp/Hel assay did not cross-react with SARS-CoV and MERS coronaviruses and revealed high sensitivity and specificity for COVID-19 (Chan et al. 2020b).

\section{In-silico approach}

Kellner et al. demonstrated that the CRISPR-based SHERLOCK (Specific High-Sensitivity Enzymatic Reporter UnLOCKing) technique could be a diagnostic tool for COVID-19 to enable compact, multiplexed and ultrasensitive detection of RNA or DNA from clinically relevant samples (Kellner et al. 2019). SHERLOCK assays are set up with recombinase-mediated polymerase pre-amplification of DNA or RNA and subsequent Cas13-or Cas12-mediated detection via colorimetric read-outs and fluorescence. Cas13a can detect new coronavirus in the given sample. By using synthetic RNA fragments of the SARS-CoV-2 virus, target sequences of SARS-CoV-2 can be detected between 20 and $200 \mathrm{aM}$ (10-100 copies per microliter of input). To improve the precision of the detection, scientists have implemented sequences unique to the current coronavirus to avoid interaction with the genomes of respiratory viruses. While the test has better readability without any difficulty, the testing of multiple patient samples also needs confirmation.

Till date, therapeutic approaches are still under trial. Cava et al. defined new functions and pathways of ACE2correlated genes using gene expression profiles from the public datasets. Researchers found a network of 193 genes, 22 interactions and 36 possible drugs, including nimesulide, fluticasone propionate, thiabendazole and photofrin. Among all the potentially active drugs, didanosine is a real antiviral drug, while the others are mostly anti-inflammatory (Cava et al. 2020). Since sialic acids linked to glycoproteins and gangliosides and are used as invasive receptors by a wide range of viruses (Matrosovich et al. 2015). Several modeling approaches have been used to decipher protein molecular mechanisms sugar interactions that account for the interaction of viruses, membranes and amyloid proteins with cell surface glycolipids (Yahi and Fantini 2014; Flores et al. 2019).

The molecular mechanisms underlying the antiviral mechanisms of chloroquine against SARS-CoV-2 infection was unraveled using novel in-silico strategy (Fantini et al. 2020). EK1C4 is an inhalation formulation for SARS-CoV-2 patients to reduce viral loads in the lungs. Recently, Xia et al. stated that EK1C4 might help to prevent SARS-CoV-2 infection due to the high retention of its target. Peptide drugs are usually safer than chemical drugs, and EK1C4 is considered to be harmless for humans (Xia et al. 2020). While no successful drugs available against COVID-19, Joshi et al. conducted a nucleocapsid virtual screening of 318 phytochemicals against molecular targets such as main protease (Mpro) and ACE2. This study identified 11 plants for their antiviral, antibacterial and antifungal activity based on low binding energy compared to the reference molecule (Joshi et al. 2020). Sekiou et al. compared the efficacy of hydroxychloroquine, Quercetin, Hispidulin, Cirsimaritin, Sulfasalazine, Artemisin and Curcumin natural compounds against COVID-19 using AutoDock indicated that these compounds have better potential inhibition than hydroxychloroquine (Omar et al. 2020).

\section{Current therapeutic option}

Coronavirus belongs to a large family of viruses found in various types of animals, including caterpillars, bats, and camels. The newly discovered strain of this virus has been established as the cause of respiratory disease in humans. Occasionally, animal coronavirus has jumped to species and eventually infected humans so that it can appear more between humans, such as MARS-CoV, SARS-CoV, and now SARS-CoV2. Some countries are likely to have distributed COVID-19 in the early stages, before any inaccurate measurements. Nevertheless, Anderson and his colleagues suggest that while governments would not be able to reduce the death rate of COVID-19 infections, the remission of this pandemic may have an immense economic effect on a viral spread (Anderson et al. 2020). To date, there are no definite treatments available to cure it. However, medical professionals are still looking for the best way to prevent these infections. People are now seeking alternative remedies to prevent their infections as a pandemic, which means that they could be globally prevalent.

\section{Antivirus therapy}

Drug therapy that is already approved for the treatment of other infectious diseases, including Ebola, Aids, HIV, malaria, is beneficial for the treatment of COVID-19. Apart from this antibodies-based protein processed using 
recombinant technology and injected into the patient body can binds to SARS-CoV-2. This method can be a promising alternative that minimize the inflammation caused due the virus. Other therapeutic strategies, such as corticosteroids for viral therapy, are not recommended. Several drug therapies have been suggested based on current published evidence, such as lopinavir with a combination of ritonavir $(400+100 \mathrm{mg})$, chloroquine $(500 \mathrm{mg})$, and hydroxychloroquine (200 mg) per $12 \mathrm{~h}$ (Cascella et al. 2020). Recently, several preclinical studies have indicated that remdesivir has an inhibitory activity of RNA polymerase in vitro against RNA viruses, including Ebola, MERS-CoV and $\mathrm{HCoV}$ infections (Gordon et al. 2020; de Wit et al. 2020). Nowadays, in the USA, this drug has been re-used for the treatment of COVID-19. Recently, the new antiviral medication favipiravir (FabiFlu) has been approved in India to combat mild to moderate cases of COVID-19 (https://timesofindia.india times.com/life-style/health-fitness/health-news/coronaviru s-vaccine-roundup-from-imperial-college-human-trials-totreatment-here-are-all-the-fresh-updates-around-covid-19/ photostory/76644042.cms). Traditional antiviral medications with a different formulations used in covid-19 therapy have been shown in Table 1 .

\section{Plasma therapy}

Among the various treatment strategies, convalescent plasma therapy (CPT) is commonly prescribed for the treatment of COVID-19. Plasma, which is only a short-term solution for susceptible people after two weeks of healing, should be used to ensure high neutralisation of antibodies. Now, we need a good design of clinical trials and a well-managed plasma therapy program to prevent COVID-19 infection (Verma et al. 2020a). Convalescent plasma transfusion from the recovered infected patient to newly infected patients can kick-start their immune system. Rajendran et al. found that, firstly, these treatments could reduce the mortality rate in critically ill patients. Second, it improved the neutralization of antibodies in newly infected patients. Thirdly, decreased flu-like symptoms, and other beneficial effects have been shown following administration of plasma therapy (Rajendran et al. 2020). Since this is just part of the treatment, there is no full solution for patients and their reaction can vary from individual to individual receiving plasma transfusion therapy (Table 2).

\section{Antibodies}

Based on the recently available study, the case fatality rate (CFR) of COVID-19 is unknown; more detailed studies are needed for identifying the actual number of infected individuals in any population. Nonetheless, we are oblivious to any completed large-scale serological survey of COVID-19 antibody detection. However, Immunotherapy may be a safer choice before the development of the vaccine that helps in developing and innate immunity to the virus. In addition, herd immunity is an alternative idea for combating COVID19 by improving natural immunity in underdeveloped countries. In Sweden, the approach to herd immunity has been updated with significant criticism (Kwok et al. 2020). Furthermore, the monoclonal antibody will be a potential therapeutic intervention for treatment against COVID 19. The monoclonal antibodies developed against the virus are listed in Table 3.

\section{Vitamin}

Recently researchers have been found that vitamin plays a vital role in clinical therapies. For instance, vitamin D boosts cellular immunity by reducing the cytokine storm in COVID-19 by inducing pro and anti-inflammatory factors, and it also acts as a modulator of adaptive immunity (Cantorna 2010; Rondanelli et al. 2018; Grant et al. 2020). For infected patient's vitamin D might be a useful medication

Table 1 List of potential alternative drugs for treatment of COVID-19

\begin{tabular}{|c|c|c|c|c|c|}
\hline S.N. & Therapeutic drug & Common name & Target & Effective concentration EC 50 & References \\
\hline 1 & Favipiravir (T-705) & Avigan & Influenza & $61.88 \mu \mathrm{M}$ & Sui et al. (2004) \\
\hline 2 & Remdesivir (GS5734) & & Ebola & $0.77 \mu \mathrm{M}$ & Sui et al. (2004) \\
\hline 3 & $\begin{array}{l}\text { Chloroquine /hydroxychlo- } \\
\text { roquine }\end{array}$ & Aralen/plaquenil & Malaria & $1.13 \mu \mathrm{M}$ & Sui et al. (2004) \\
\hline 4 & Lopinavir/ritonavir & Kaletra & HIV & & \\
\hline 5 & $\begin{array}{l}\text { Pegylated interferon with } \\
\text { ribavirin }\end{array}$ & Virazole & $\mathrm{HBV}, \mathrm{HCV}$ & $109 \mu \mathrm{M}$ & Sui et al. (2004) \\
\hline 6 & Teicoplanin & - & MERS-CoV and SARS-CoV & $1.66 \mu \mathrm{M}$ & Zhai et al. (2020) \\
\hline 7 & Arbidol tablets & - & SARS-CoV 2 & Under clinical trial & \\
\hline 8 & Methylprednisolone & - & $\begin{array}{l}\text { Severe novel coronavirus } \\
\text { pneumonia: }\end{array}$ & Under clinical trial & \\
\hline 9 & Nelfinavir (HIV-protease) & - & SARS-CoV & & Yamamoto et al. (2004) \\
\hline
\end{tabular}




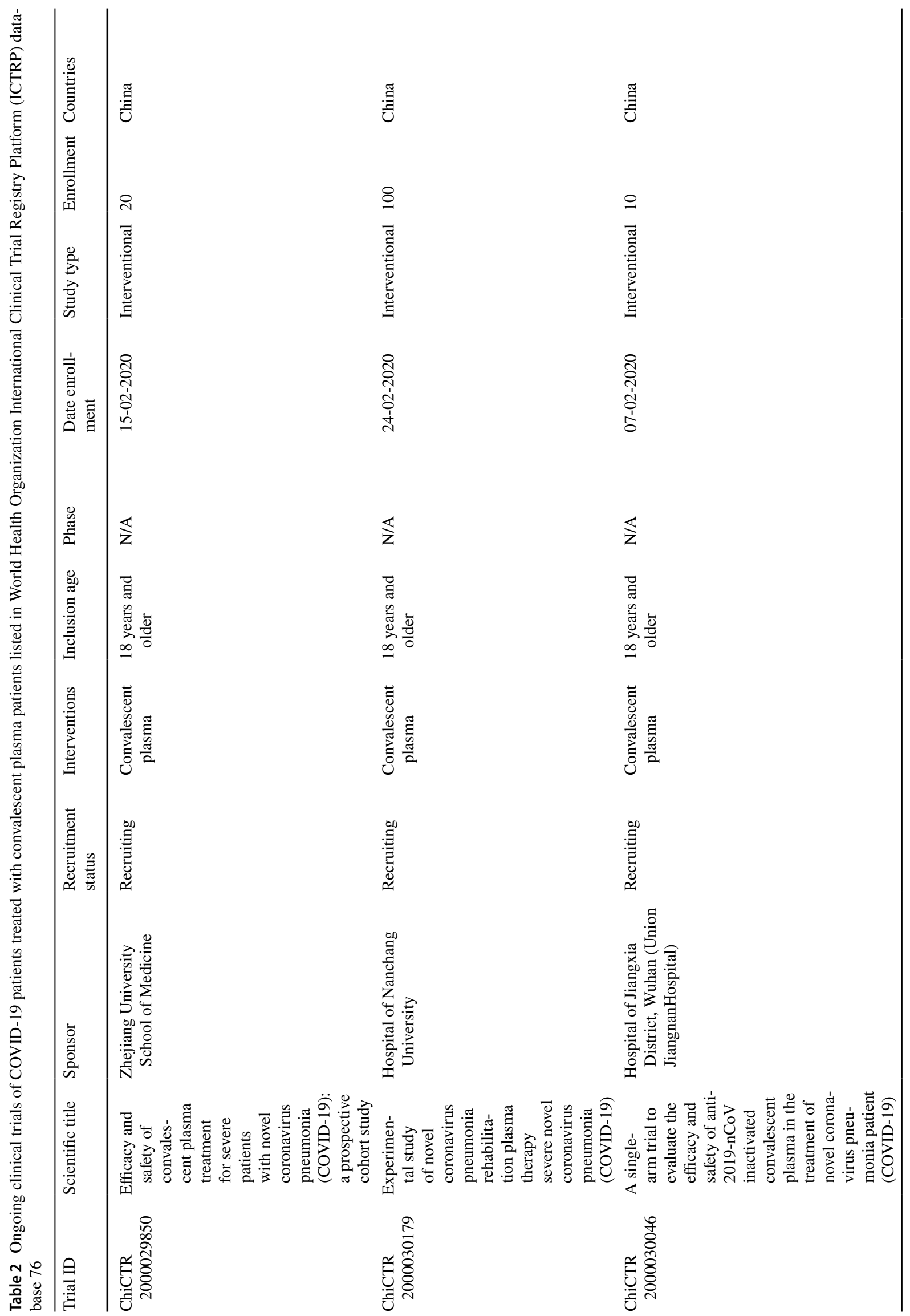




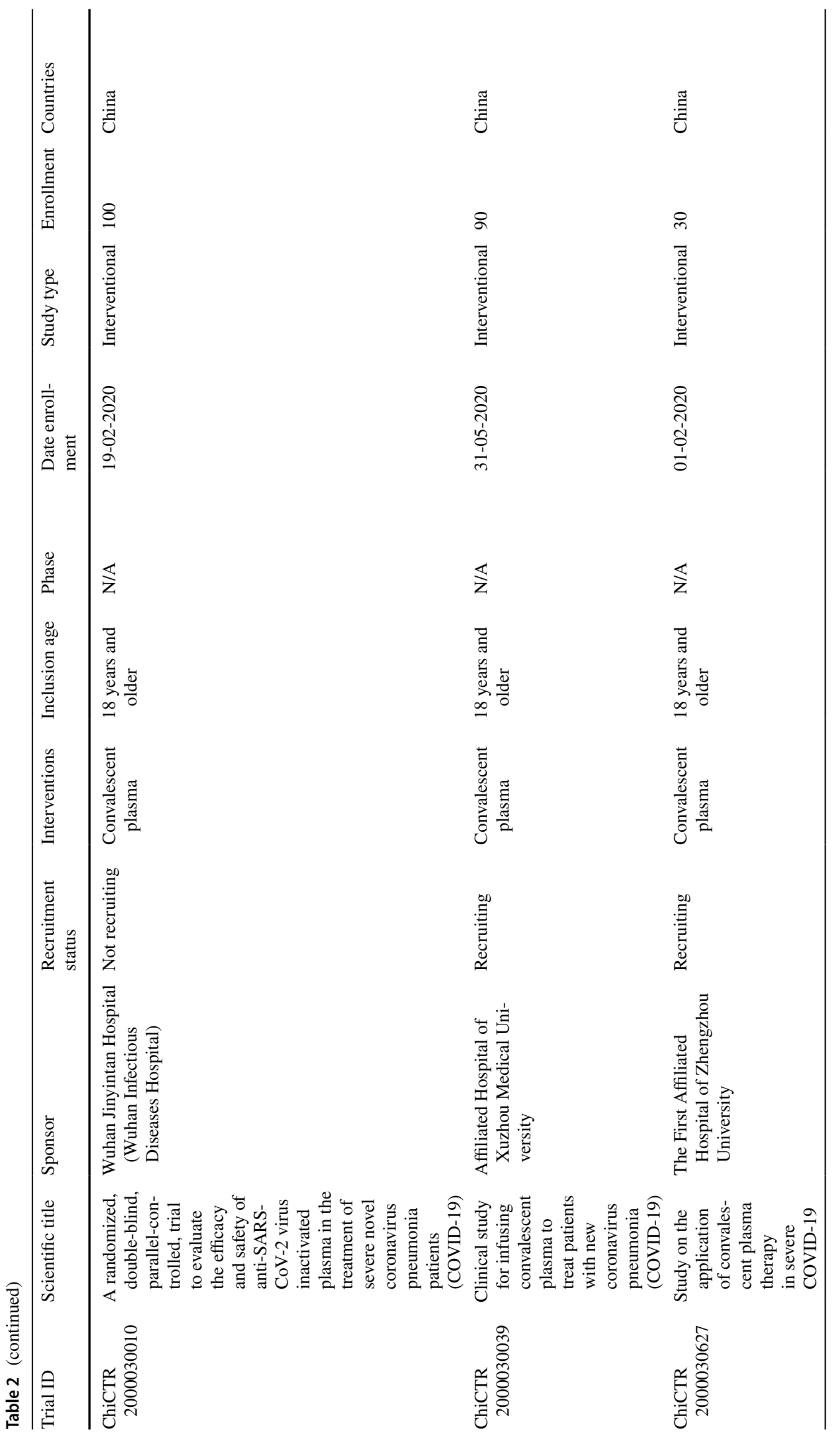




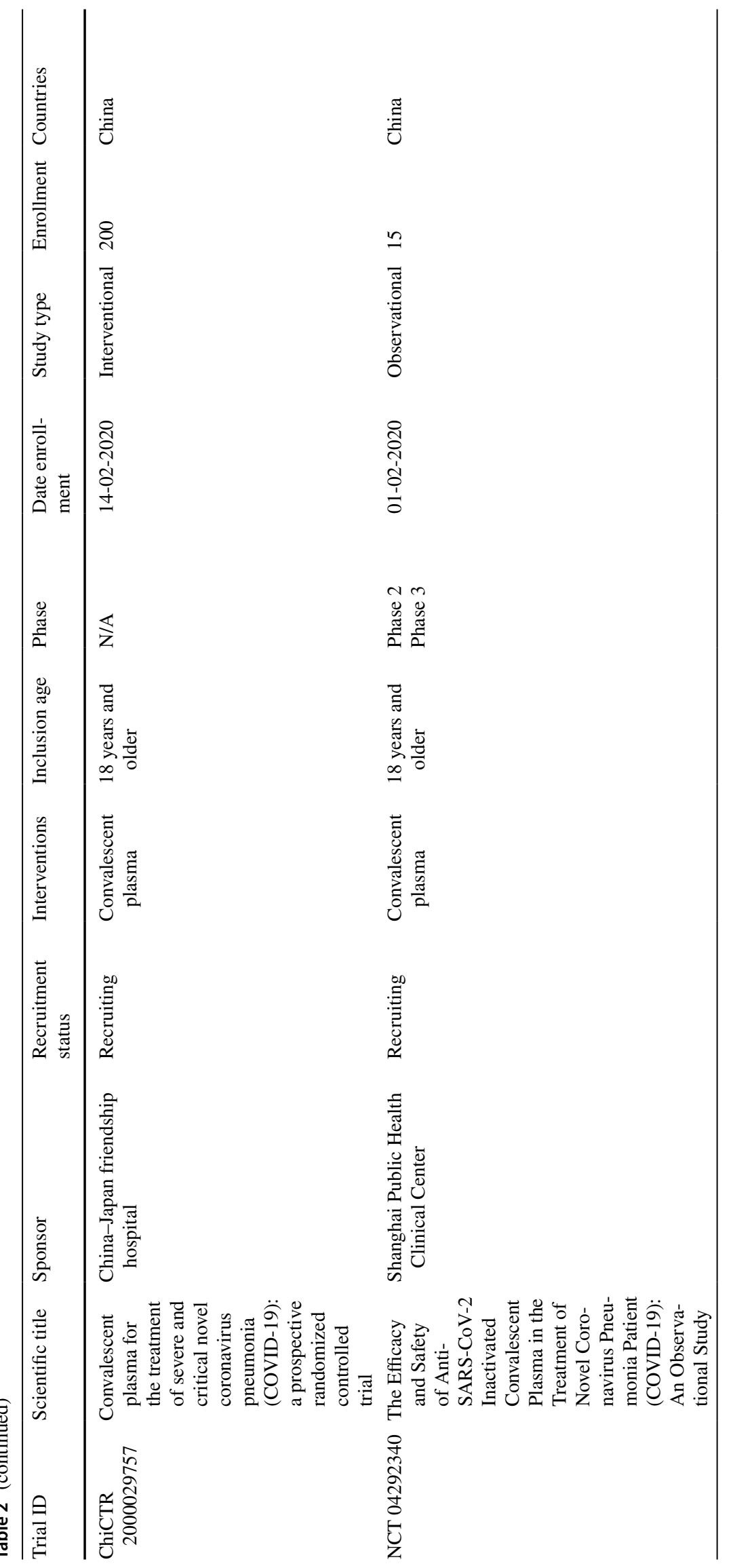




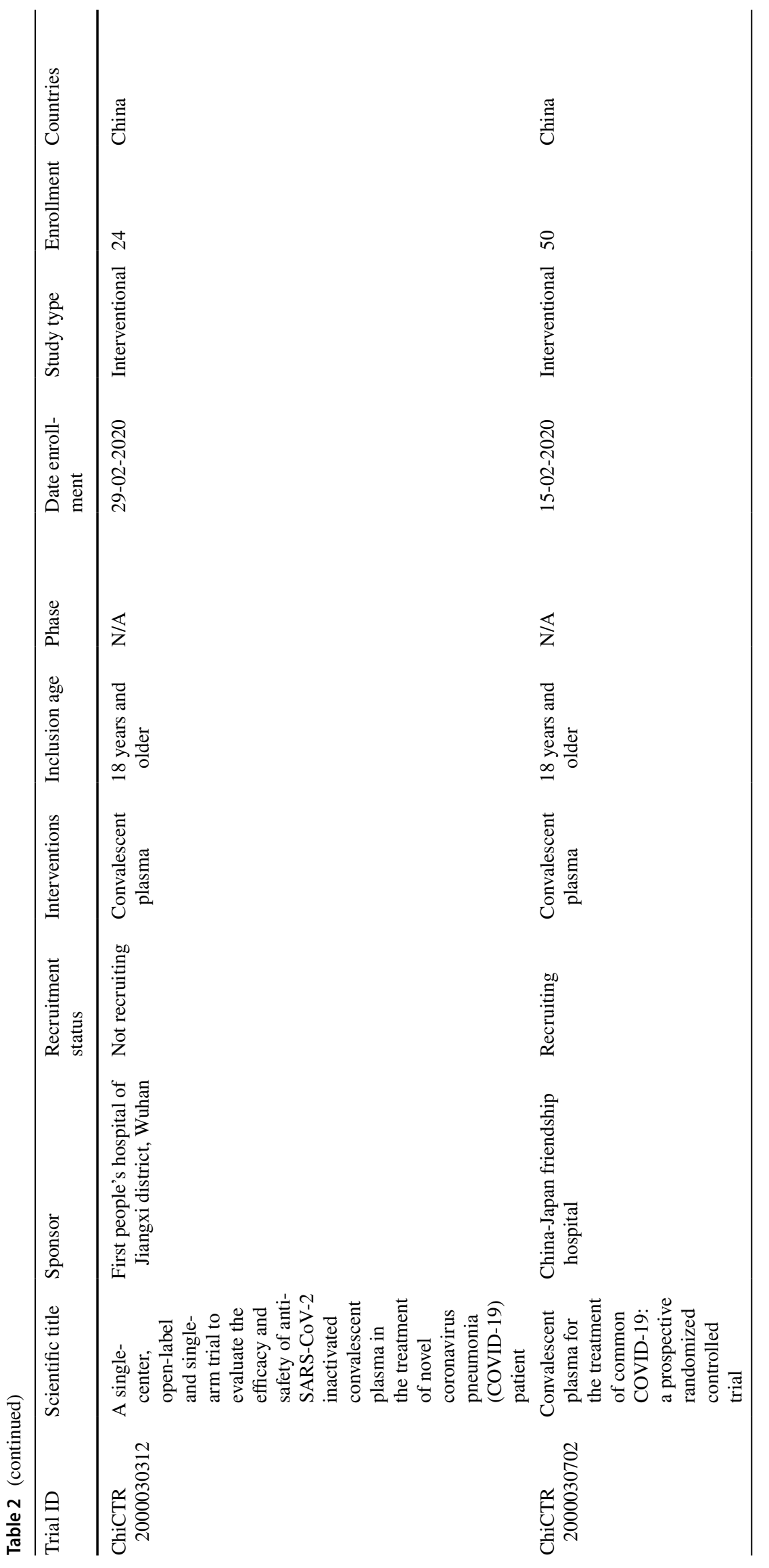




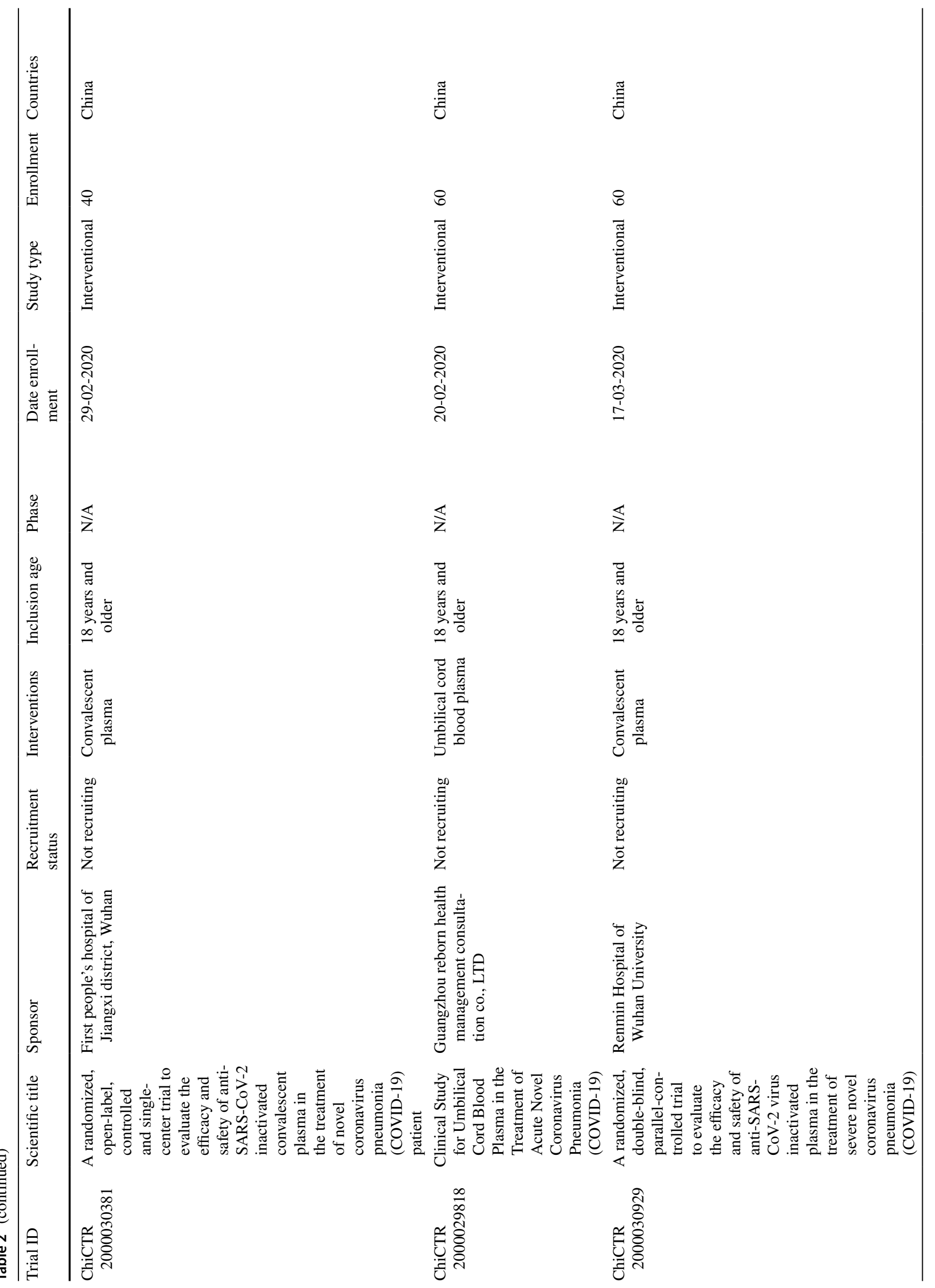




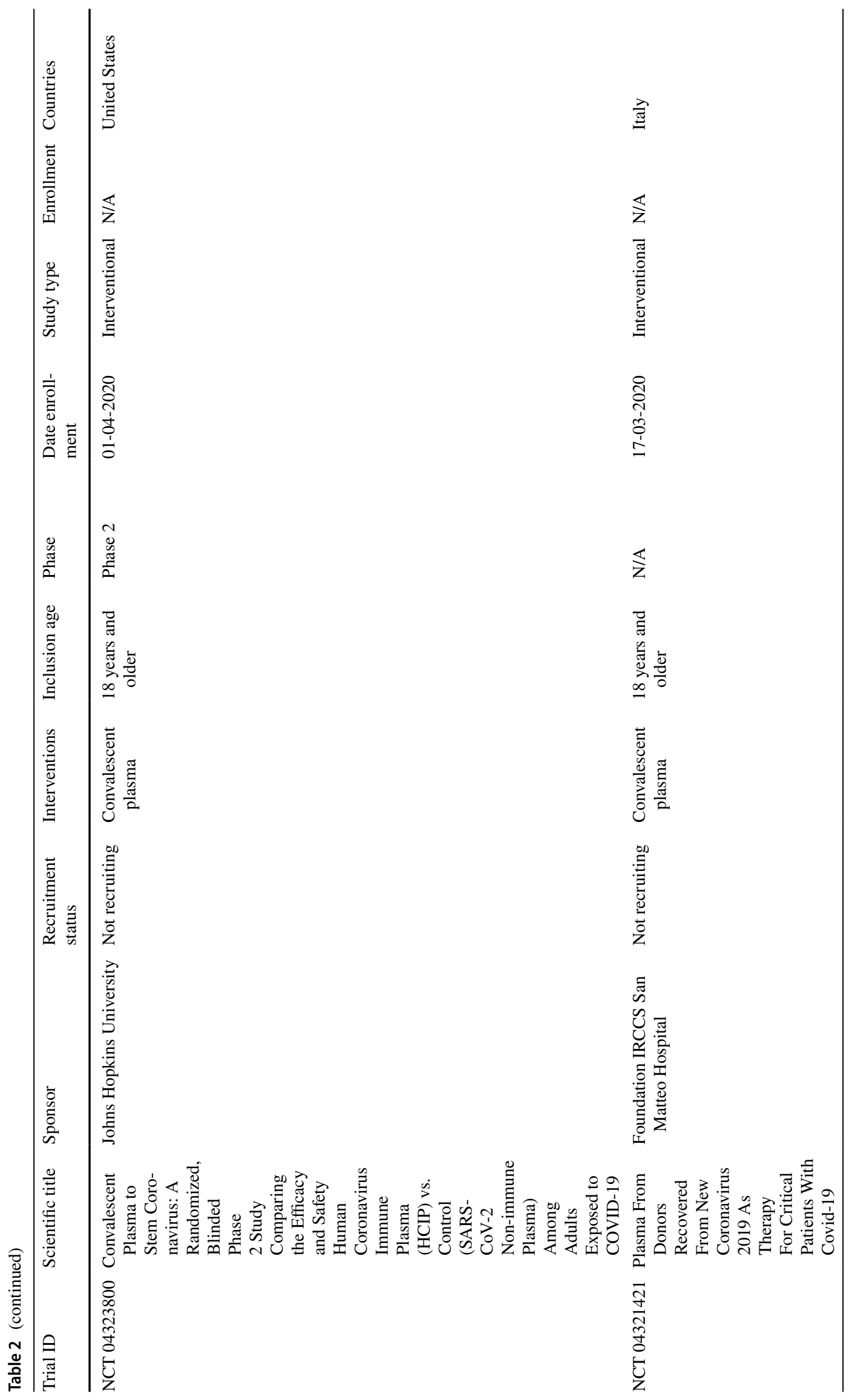




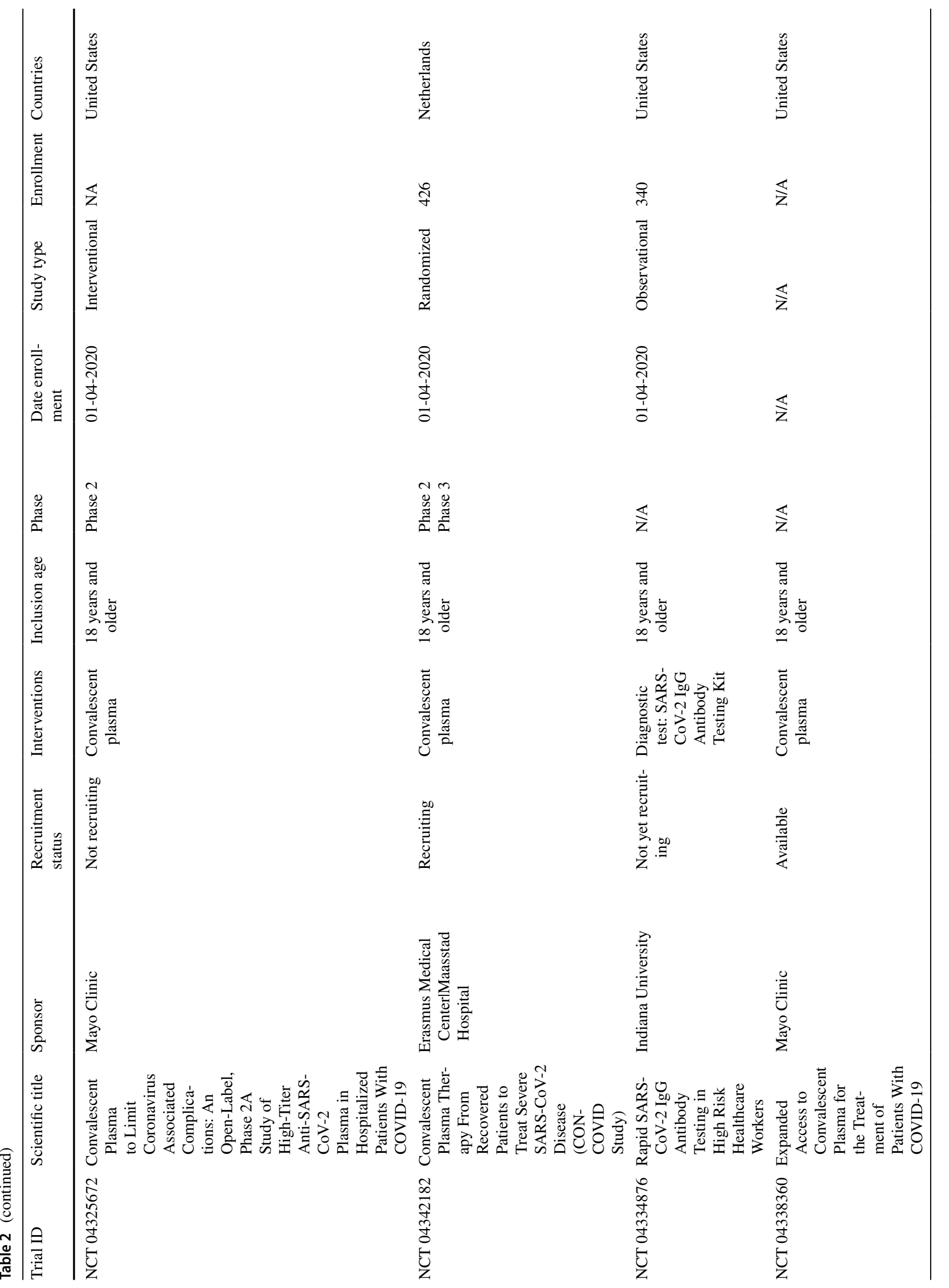




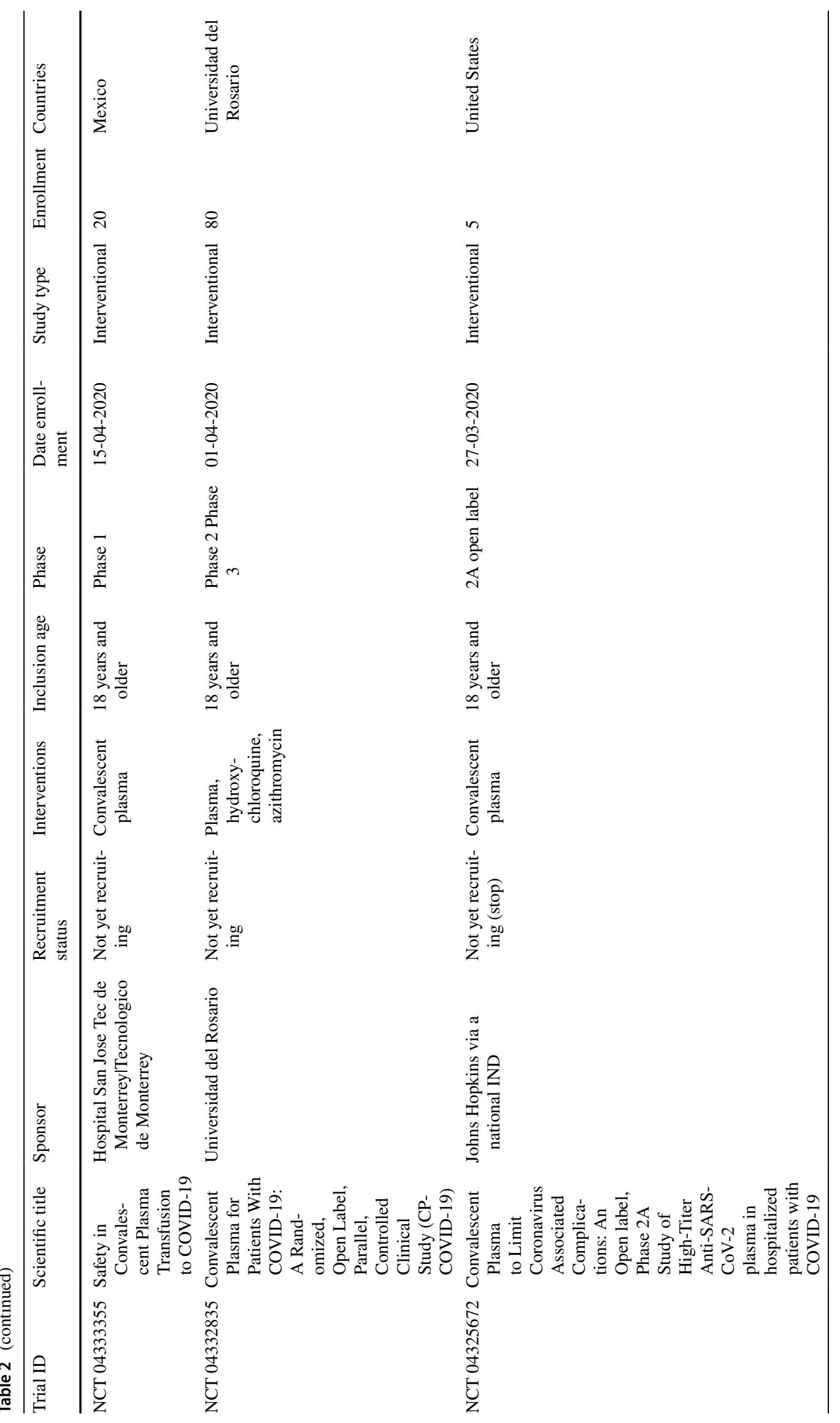




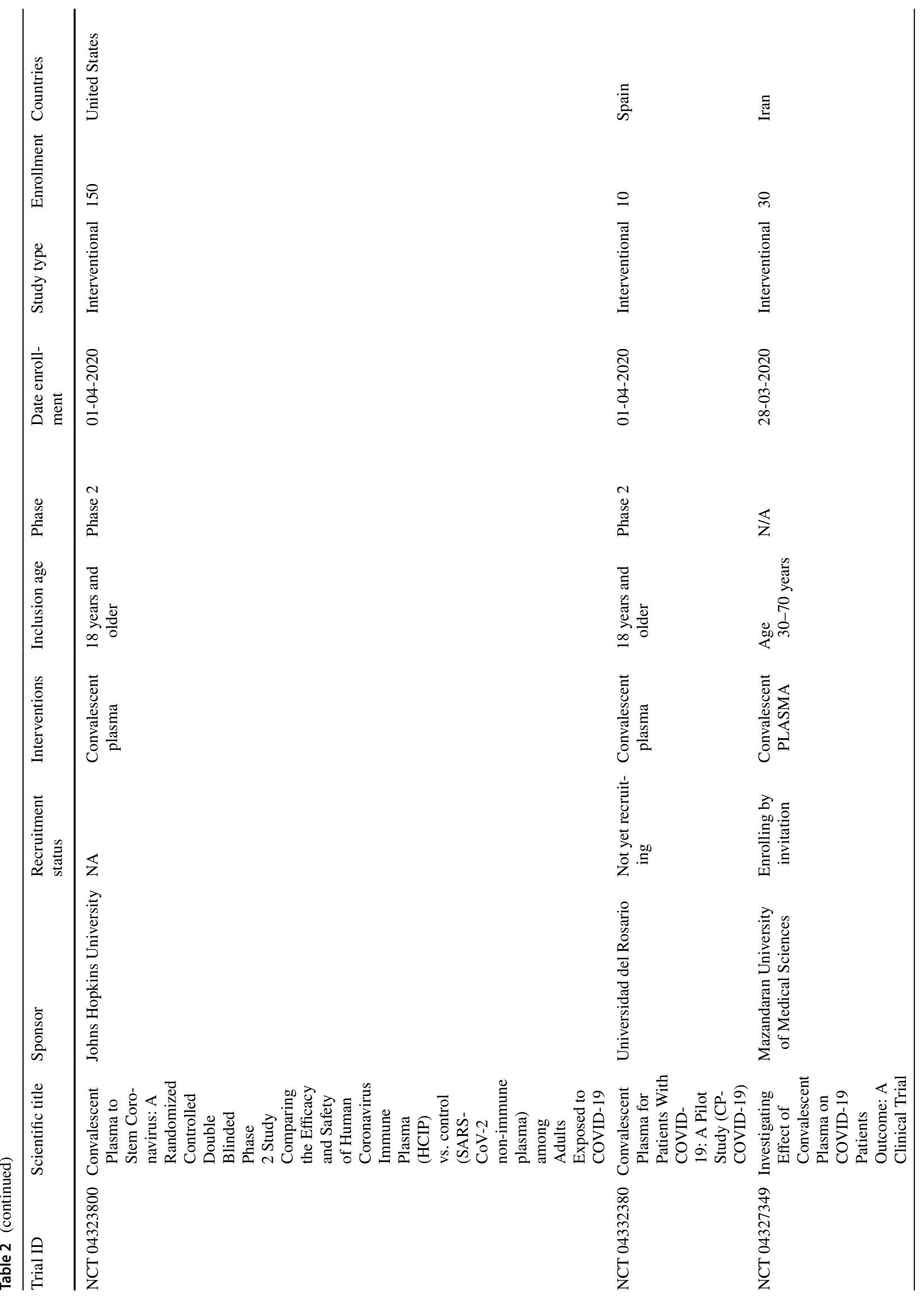




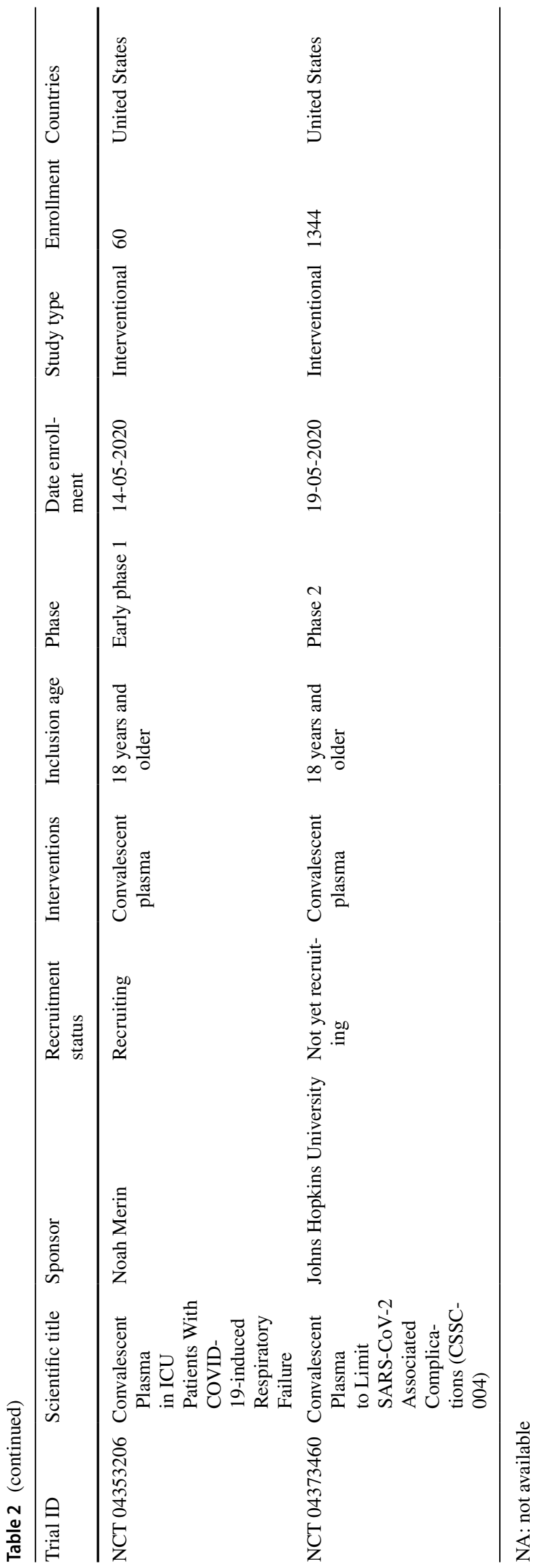

to prevent infections. Many reviews are suggesting that vitamin D loading doses of 200,000-300,000 IU capsules reduces the risk and severity of COVID-19 (Gasmi et al. 2020). Some recommended vitamin with their doses listed in Table 4.

\section{Summary of meta-analysis}

To date, several research groups are trying to resolve the present pandemic problem. In this perspective, many reaserchers have summarised reliable medical evidence by the metaanalysis of all published clinical trials against COVID-19, among them ten meta-analyses we have included with either therapeutic target as vaccines or placebo infections, chloroquine derives hydroxy-chloroquine, dexamethasone, lopinavir-ritonavir, remdesivir with placebo, hydroxy-chloroquine with azithromycin, tocilizumab, convalescent plasma. The results of all meta-analysis were inconsistent (Table 5).

\section{Other treatments}

In the current scenario, most of the studies using western medicine for the treatment of COVID-19 but Chinese traditional medicine also has a potential activity for COVID19 (Zhang et al. 2020a). According to the latest clinical guidelines for the treatment of SARS or MERS patients are same, and both western medicine and traditional Chinese medicine are used for the treatment of COVID-19 in China (Li and De Clercq 2020; Li and Peng 2013). Due to the genomic homology, clinical evidence shows the safety and efficacy of traditional Chinese medicine in the treatment of COVID-19. Some of them include herbal folk therapies and herbal teas. It also suggested that some of them might not be safe to consume (Coghlan et al. 2015). According to the Ministry of AYUSH (Ayurveda, Yoga and Naturopathy, Unani, Siddha and Homeopathy), Government of India, herbal medicines may helpful to combat the corona outbreak and at least reduce the infection. An autonomous body of AYUSH, CCRAS (Central Council for Ayurvedic Sciences Research), had developed AYUSH-64 for effective treatment without malaria. Scientific experts recommending that there is no adequate evidence for the use of Arsenicum Album in the fight against the symptoms of COVID-19. Besides, homoeopathy derived arsenic was recommended to take on an empty stomach. Due to the immunity boosting properties, anti-inflammatory ayurvedic drugs were also used against coronavirus. An evidence-based study shows that the intake of the antimalarial ayurvedic drugs (Ayush 64) developed by the Indian Ministry has a beneficial effect on COVID-19 (CCMI 2020). 
Table 3 List of neutralizing monoclonal antibody and protease inhibitors

\begin{tabular}{|c|c|c|c|c|}
\hline S.N. & Name & Experimental model & Mechanism & References \\
\hline 1 & Anti-ACE2 & Mouse & $\begin{array}{l}\text { Target the spike protein of SARS-CoV-2 that } \\
\text { inhibits virus binding cell receptors }\end{array}$ & Shanmugaraj et al. (2020) \\
\hline 2 & CR3014 & Ferret and in vitro & $\begin{array}{l}\text { Binding to the } 318-510 \text { amino acid residues with } \\
\text { high affinity on S1 fragment of SARS-CoV and- } \\
\text { block the interaction of S1 subunit protein with } \\
\text { cellular receptor ACE2 in vitro and in vivo }\end{array}$ & $\begin{array}{l}\text { van den Brink et al. (2005), ter Meulen et al. } \\
\text { (2006), Jan ter Meulen et al. (2004) }\end{array}$ \\
\hline 3 & CR3022 & In vitro & $\begin{array}{l}\text { Binding to the } 318-510 \text { amino acid residues } \\
\text { on S1 fragment of SARS-CoVand block the } \\
\text { interaction of S1 subunit protein with cellular } \\
\text { receptor ACE2 }\end{array}$ & ter Meulen et al. (2006) \\
\hline 4 & F26G18 & In vitro & $\begin{array}{l}\text { Binding to the linear epitope } 460-476 \text { amino acid } \\
\text { residues on S1 fragment of SARS-CoVand } \\
\text { block the interaction of S1 subunit protein with } \\
\text { cellular receptor ACE2 }\end{array}$ & Berry et al. (2010) \\
\hline 5 & F26G19 & In vitro & $\begin{array}{l}\text { Binding to the conformational epitope (amino } \\
\text { acid residues 359-362, 391-392, 424-427, and } \\
\text { 486-492) on S1 fragment of SARS-CoVand } \\
\text { block the interaction of S1 subunit protein with } \\
\text { cellular receptor ACE2 }\end{array}$ & Berry et al. (2010) \\
\hline 6 & m396 & In vitro & $\begin{array}{l}\text { Binding to the conformational epitope amino acid } \\
\text { residues } 482-491 \text { on S1 fragment of SARS- } \\
\text { CoV and block the interaction of S subunit } \\
\text { protein using CDR loops H1, H2, H3, and L3 } \\
\text { with cellular receptor ACE2 }\end{array}$ & Berry et al. (2010), Zhu et al. (2007) \\
\hline 7 & $1 \mathrm{~A} 9$ & In vitro & $\begin{array}{l}\text { Binding to the Heptad repeat loops, including } \\
\text { heptad repeat one and heptad repeat one domain } \\
\text { on S2 fragmentof SARS-CoV and block the } \\
\text { interaction of S2 subunit protein with cellular } \\
\text { receptorACE2 }\end{array}$ & Ng et al. (2014), Lip et al. (2006) \\
\hline 8 & 201 & $\begin{array}{l}\text { Mouse Syrian Ham- } \\
\text { ster and in vitro }\end{array}$ & $\begin{array}{l}\text { Binding to the } 490-510 \text { amino acid residues } \\
\text { on } \mathrm{S} 1 \text { fragment of SARS-CoV and block the } \\
\text { interaction of S1 subunit protein with cellular } \\
\text { receptor ACE2 in vitro and in vivo }\end{array}$ & $\begin{array}{l}\text { Greenough et al. (2005), Coughlin and Prabhakar } \\
\text { (2012) }\end{array}$ \\
\hline 9 & 4D4 & in vitro & $\begin{array}{l}\text { Binding to the } 12-261 \text { amino acid residues of } \\
\text { SARS-CoV and N-terminal of RBD and Inhibit } \\
\text { the post-interaction in the viral permeation }\end{array}$ & $\begin{array}{l}\text { Coughlin and Prabhakar (2012), Elshabrawy et al. } \\
\text { (2012) }\end{array}$ \\
\hline 10 & $\mathrm{~S} 230$ & in vitro & $\begin{array}{l}\text { Binding to epitopes partially overlapping with } \\
\text { receptor binding motifs on B domain of SARS- } \\
\text { CoVand block the interaction of S1 subunit } \\
\text { protein with cellular receptor ACE2 in vitro }\end{array}$ & Walls et al. (2019) \\
\hline
\end{tabular}

Table 4 List of important recommended vitamins and their dosages for treatment of COVID-19

\begin{tabular}{|c|c|c|c|c|c|c|}
\hline S.N. & Vitamin name & Age group & Recommended dose & Disease & Target & References \\
\hline 1 & 25-hydroxyvitamin D & 0-95 year & $\begin{array}{l}\text { Daily or weekly } \\
2000 \mathrm{IU} / \text { day }(50 \mu \mathrm{g} / \\
\text { day) }\end{array}$ & $\begin{array}{l}\text { Acute respiratory tract } \\
\text { infection }\end{array}$ & Reduce inflammation & $\begin{array}{l}\text { Martineau et al. (2017), } \\
\text { Autier et al. (2017), } \\
\text { Martineau et al. } \\
\text { (2019), Rejnmark } \\
\text { et al. (2017), Berg- } \\
\text { man et al. (2013), } \\
\text { Charan et al. (2012) }\end{array}$ \\
\hline 2 & $\begin{array}{l}\text { Vitamin-E (Tocoph- } \\
\text { erol) }\end{array}$ & All age & $\begin{array}{l}\text { One-year daily sup- } \\
\text { plement }\end{array}$ & $\begin{array}{l}\text { Respiratory tract } \\
\text { infection }\end{array}$ & $\begin{array}{l}\text { Enhance T-cell medi- } \\
\text { ated immunity }\end{array}$ & $\begin{array}{l}\text { Wu and Meydani } \\
\text { (2014) }\end{array}$ \\
\hline 3 & $\begin{array}{l}\text { Vitamin-C (Ascorbic } \\
\text { acid) }\end{array}$ & $1-3$ year to adult & $\begin{array}{l}\text { Least } 200 \mathrm{mg} / \text { day-2 g/ } \\
\text { day }\end{array}$ & $\begin{array}{l}\text { Upper and lower } \\
\text { respiratory tract } \\
\text { infection }\end{array}$ & & Monsen (2000) \\
\hline
\end{tabular}


Table 5 Summary of meta-analysis conducted by several groups for the treatment of COVID-19

\begin{tabular}{|c|c|c|c|c|c|}
\hline S.N. & Therapeutic drug & Common name & Target & Comments/significance & References \\
\hline 1 & $\begin{array}{l}\text { Chloroquine derives hydroxy- } \\
\text { chloroquine }\end{array}$ & Aralen/plaquenil & SARS-CoV 2 & $\begin{array}{l}\text { More useful to improve clinical } \\
\text { and virological outcomes. } \\
\text { But reduce mortality }\end{array}$ & $\begin{array}{l}\text { Million et al. (2020), Pathak } \\
\text { et al. (2020), Siemieniuk et al. } \\
\text { (2020) }\end{array}$ \\
\hline 2 & Dexamethasone & Decadron & SARS-CoV 2 & $\begin{array}{l}\text { Risk of mortality and benefits } \\
\text { for severing clinical condi- } \\
\text { tion patients }\end{array}$ & $\begin{array}{l}\text { Abeldano Zuniga et al. (2020), } \\
\text { Siemieniuk et al. (2020) }\end{array}$ \\
\hline 3 & Lopinavir-Ritonavir & Kaletra & HIV, SARS-CoV 2 & $\begin{array}{l}\text { Risk of mortality, adverse } \\
\text { events }\end{array}$ & $\begin{array}{l}\text { Abeldano Zuniga et al. (2020), } \\
\text { Siemieniuk et al. (2020) }\end{array}$ \\
\hline 4 & Remdesivir with placebo & Veklury & Ebola, COVID-19 & Risk of mortality & $\begin{array}{l}\text { Abeldano Zuniga et al. (2020), } \\
\text { Siemieniuk et al. (2020) }\end{array}$ \\
\hline 5 & $\begin{array}{l}\text { Hydroxy-chloroquine with } \\
\text { azithromycin }\end{array}$ & $\begin{array}{l}\text { Aralen/plaquenil } \\
\text { and zitromax }\end{array}$ & SARS-CoV 2 & $\begin{array}{l}\text { Not alter the rate of risk of } \\
\text { virologic cure and risk of } \\
\text { mortality, Not different from } \\
\text { hydroxy-chloroquine alone }\end{array}$ & $\begin{array}{l}\text { Ayele Mega et al. (2020), Chen } \\
\text { et al. (2020c), (Tang et al. } \\
\text { (2020), Fiolet et al. (2020), } \\
\text { Abeldano Zuniga et al. } \\
\text { (2020), Siemieniuk et al. } \\
(2020)\end{array}$ \\
\hline 6 & Tolicizumab & Actemra & & Lower mortality was $12 \%$ & Malgie et al. (2020) \\
\hline 7 & Convalescent Plasma & NA & SARS-CoV 2 & $\begin{array}{l}\text { Mortality and virological } \\
\text { clearance }\end{array}$ & $\begin{array}{l}\text { Abeldano Zuniga et al. (2020), } \\
\text { Siemieniuk et al. (2020) }\end{array}$ \\
\hline 8 & Vaccine vs placebo & NA & SARS-CoV 2 & $\begin{array}{l}\text { Significantly increase } \mathrm{IgG} \\
\text { level than placebo, total } \\
\text { local events also changed } \\
(P>0.05)\end{array}$ & Yuan et al. (2020) \\
\hline
\end{tabular}

\section{Conclusion}

The advancement of COVID-19 infection depends upon the interface between the load of the virus and the human immune system. As the global demand for diagnosis and therapy continues to rise, it is essential to quickly develop various algorithms to identify and contain the virus successfully. The pathogenic effects of the virus tend to be mediated by binding to human receptor ACE2. If the virus has a high load in an individual, the level of infection could increase the number of deaths. Conversely, due to the undetectable virulence load, moderate and lower viral load displays falsenegative effects. This load of virulence is determined by gender, age, nutritional status, dietary habits, co-morbidity, and physical condition. These parameters play a contributing role in the severity of the disease and the re-infection of individuals. From this perspective, it is essential to develop new, fast, reliable, feasible, compact and straight forward technologies for the detection of COVID-19. The worldwide collaboration of healthcare professionals to engage patients in clinical trials is essential. A multicentre mega-trial is vital for comparing the clinical outcome of patients treated with different combination drugs. There is no doubt that researchers are directed to gain insight into this disease and to develop an effective therapeutic option. As far as management is concerned, the first step that can be taken is to get the right advice and clear people's fears. Besides, much-fabricated knowledge about COVID-19 is being disseminated, which has triggered fear in society. Clear guidelines should be implemented at the group level, which will help patients heal as quickly as possible. Meantime, research will continue, and CP therapy or neutralizing antibodies are considered for treatment until the vaccine arrives.

Author contributions The authors HKV conceived the study, RKR, $\mathrm{NK}, \mathrm{AB}$ retrieved the data and $\mathrm{HKV}, \mathrm{RKR}, \mathrm{NK}, \mathrm{AB}$, and BLVKS wrote the manuscript and approved the final version and made manuscript technically sound.

\section{Compliance with ethical standards}

Conflict of interest The authors declare no conflict of interest.

Consent for publication All the authors have read the manuscript and have approved this submission.

\section{References}

Abeldano Zuniga RA, Coca S, Abeldano G, Gonzalez Villoria RAM (2020) Clinical effectiveness of drugs in hospitalized patients with COVID-19 infection: a systematic review and meta-analysis. medRxiv. https://doi.org/10.1101/2020.09.11.20193011

Anderson RM, Heesterbeek H, Klinkenberg D, Hollingsworth TD (2020) How will country-based mitigation measures influence the course of the COVID-19 epidemic? Lancet 395(10228):931934. https://doi.org/10.1016/S0140-6736(20)30567-5

Autier P, Mullie P, Macacu A, Dragomir M, Boniol M, Coppens K, Pizot C (2017) Effect of vitamin D supplementation on 
non-skeletal disorders: a systematic review of meta-analyses and randomised trials. Lancet Diabetes Endocrinol 5(12):9861004. https://doi.org/10.1016/S2213-8587(17)30357-1

Ayele Mega T, Feyissa TM, Dessalegn Bosho D, Kumela Goro K, Zeleke Negera G (2020) The outcome of hydroxychloroquine in patients treated for COVID-19: systematic review and meta-analysis. Can Respir J 2020:4312519. https://doi. org/10.1155/2020/4312519

Belouzard S, Chu VC, Whittaker GR (2009) Activation of the SARS coronavirus spike protein via sequential proteolytic cleavage at two distinct sites. Proc Natl Acad Sci 106(14):5871-5876. https://doi.org/10.1073/pnas.0809524106

Bennardo F, Buffone C, Giudice A (2020) New therapeutic opportunities for COVID-19 patients with tocilizumab: possible correlation of interleukin-6 receptor inhibitors with osteonecrosis of the jaws. Oral Oncol. https://doi.org/10.1016/j.oraloncolo gy.2020.104659

Benvenuto D, Giovanetti M, Ciccozzi A, Spoto S, Angeletti S, Ciccozzi M (2020) The 2019-new coronavirus epidemic: evidence for virus evolution. J Med Virol 92(4):455-459. https://doi. org/10.1002/jmv. 25688

Bergman P, Lindh AU, Bjorkhem-Bergman L, Lindh JD (2013) Vitamin $D$ and respiratory tract infections: a systematic review and meta-analysis of randomized controlled trials. PLoS ONE 8(6):e65835. https://doi.org/10.1371/journal.pone.0065835

Berry JD, Hay K, Rini JM, Yu M, Wang L, Plummer FA, Corbett CR, Andonov A (2010) Neutralizing epitopes of the SARS-CoV S-protein cluster independent of repertoire, antigen structure or mAb technology. mAbs 2(1):53-66. https://doi.org/10.4161/ mabs.2.1.10788

Bhaskar LVKS, Roshan B, Nasri H (2020) The fuzzy connection between SARS-CoV-2 infection and loss of renal function. Am J Nephrol 51(7):572-573. https://doi.org/10.1159/000508087

Bramanti B, Dean KR, Walloe L, Chr Stenseth N (2019) The third plague pandemic in Europe. Proc Biol Sci 286(1901):20182429. https://doi.org/10.1098/rspb.2018.2429

Cantorna MT (2010) Mechanisms underlying the effect of vitamin D on the immune system. Proc Nutr Soc 69(3):286-289. https ://doi.org/10.1017/S0029665110001722

Cascella M, Rajnik M, Cuomo A, Dulebohn SC, Di Napoli R (2020) Features, evaluation and treatment Coronavirus (COVID-19). StatPearls, Treasure Island

Cava C, Bertoli G, Castiglioni I (2020) In silico discovery of candidate drugs against Covid-19. Viruses. https://doi.org/10.3390/ v12040404

CCMI (2020) Central council of indian medicine telemedicine practice guidelines for Ayurveda, Siddha and Unani Practitioners

Chan JF, Yip CC, To KK, Tang TH, Wong SC, Leung KH, Fung AY, Ng AC, Zou Z, Tsoi HW, Choi GK, Tam AR, Cheng VC, Chan KH, Tsang OT, Yuen KY (2020b) Improved molecular diagnosis of COVID-19 by the novel, highly sensitive and specific COVID-19-RdRp/Hel real-time reverse transcription-PCR assay validated in vitro and with clinical specimens. J Clin Microbiol. https://doi.org/10.1128/jcm.00310-20

Chan JF, Kok KH, Zhu Z, Chu H, To KK, Yuan S, Yuen KY (2020a) Genomic characterization of the 2019 novel human-pathogenic coronavirus isolated from a patient with atypical pneumonia after visiting Wuhan. Emerg Microbes Infect 9(1):221-236. https://doi.org/10.1080/22221751.2020.1719902

Channappanavar R, Perlman S (2017) Pathogenic human coronavirus infections: causes and consequences of cytokine storm and immunopathology. Semin Immunopathol 39(5):529-539. https ://doi.org/10.1007/s00281-017-0629-x

Charan J, Goyal JP, Saxena D, Yadav P (2012) Vitamin D for prevention of respiratory tract infections: a systematic review and meta-analysis. J Pharmacol Pharmacother 3(4):300-303. https ://doi.org/10.4103/0976-500X.103685

Chen Z, Fan H, Cai J, Li Y, Wu B, Hou Y, Xu S, Zhou F, Liu Y, Xuan W, Hu H, Sun J (2020b) High-resolution computed tomography manifestations of COVID-19 infections in patients of different ages. Eur J Radiol 126:108972. https://doi.org/10.1016/j.ejrad 2020.108972

Chen C, Zhang XR, Ju ZY, He WF (2020a) Advances in the research of cytokine storm mechanism induced by Coronavirus Disease 2019 and the corresponding immunotherapies. Chin J Burns 36:E005. https://doi.org/10.3760/cma.j.cn501120-20200224-00088

Chen Z, Hu J, Zhang Z, Jiang S, Han S, Yan D, Zhuang R, Hu B, Zhang Z (2020c) Efficacy of hydroxychloroquine in patients with COVID-19: results of a randomized clinical trial. medRxiv. https ://doi.org/10.1101/2020.03.22.20040758

Cheung CY, Poon LL, Ng IH, Luk W, Sia SF, Wu MH, Chan KH, Yuen KY, Gordon S, Guan Y, Peiris JS (2005) Cytokine responses in severe acute respiratory syndrome coronavirusinfected macrophages in vitro: possible relevance to pathogenesis. J Virol 79(12):7819-7826. https://doi.org/10.1128/ JVI.79.12.7819-7826.2005

Chowdhury FR, Nur Z, Hassan N, von Seidlein L, Dunachie S (2017) Pandemics, pathogenicity and changing molecular epidemiology of cholera in the era of global warming. Ann Clin Microbiol Antimicrob 16(1):10. https://doi.org/10.1186/s12941-017-0185-1

Coghlan ML, Maker G, Crighton E, Haile J, Murray DC, White NE, Byard RW, Bellgard MI, Mullaney I, Trengove R, Allcock RJ, Nash C, Hoban C, Jarrett K, Edwards R, Musgrave IF, Bunce M (2015) Combined DNA, toxicological and heavy metal analyses provides an auditing toolkit to improve pharmacovigilance of traditional Chinese medicine (TCM). Sci Rep 5:17475. https:// doi.org/10.1038/srep17475

Coughlin MM, Prabhakar BS (2012) Neutralizing human monoclonal antibodies to severe acute respiratory syndrome coronavirus: target, mechanism of action, and therapeutic potential. Rev Med Virol 22(1):2-17. https://doi.org/10.1002/rmv.706

Cucinotta D, Vanelli M (2020) WHO declares COVID-19 a pandemic. Acta Biomed 91(1):157-160. https://doi.org/10.23750/abm. v91i1.9397

de Wit E, van Doremalen N, Falzarano D, Munster VJ (2016) SARS and MERS: recent insights into emerging coronaviruses. Nat Rev Microbiol 14(8):523-534. https://doi.org/10.1038/nrmic ro.2016.81

de Wit E, Feldmann F, Cronin J, Jordan R, Okumura A, Thomas T, Scott D, Cihlar T, Feldmann H (2020) Prophylactic and therapeutic remdesivir (GS-5734) treatment in the rhesus macaque model of MERS-CoV infection. Proc Natl Acad Sci USA 117(12):6771-6776. https://doi.org/10.1073/pnas.1922083117

Elshabrawy HA, Coughlin MM, Baker SC, Prabhakar BS (2012) Human monoclonal antibodies against highly conserved HR1 and HR2 domains of the SARS-CoV spike protein are more broadly neutralizing. PLoS ONE 7(11):e50366. https://doi.org/10.1371/ journal.pone.0050366

Fantini J, Di Scala C, Chahinian H, Yahi N (2020) Structural and molecular modelling studies reveal a new mechanism of action of chloroquine and hydroxychloroquine against SARS-CoV-2 infection. Int J Antimicrob Agents. https://doi.org/10.1016/j. ijantimicag.2020.105960

Fiolet T, Guihur A, Rebeaud ME, Mulot M, Peiffer-Smadja N, Mahamat-Saleh Y (2020) Effect of hydroxychloroquine with or without azithromycin on the mortality of coronavirus disease 2019 (COVID-19) patients: a systematic review and meta-analysis. Clin Microbiol Infect. https://doi.org/10.1016/j.cmi.2020.08.022

Flores A, Ramirez-Franco J, Desplantes R, Debreux K, Ferracci G, Wernert F, Blanchard MP, Maulet Y, Youssouf F, Sangiardi M, Iborra C, Popoff MR, Seagar M, Fantini J, Lévêque C, El 
Far O (2019) Gangliosides interact with synaptotagmin to form the high-affinity receptor complex for botulinum neurotoxin B. Proc Natl Acad Sci USA 116(36):18098-18108. https://doi. org/10.1073/pnas.1908051116

Gasmi A, Noor S, Tippairote T, Dadar M, Menzel A, Bjørklund G (2020) Individual risk management strategy and potential therapeutic options for the COVID-19 pandemic. Clin Immunol 215:108409-108409. https://doi.org/10.1016/j.clim.2020.108409

Gavriatopoulou M, Korompoki E, Fotiou D, Ntanasis-Stathopoulos I, Psaltopoulou T, Kastritis E, Terpos E, Dimopoulos MA (2020) Organ-specific manifestations of COVID-19 infection. Clin Exp Med. https://doi.org/10.1007/s10238-020-00648-X

Gordon CJ, Tchesnokov EP, Feng JY, Porter DP, Gotte M (2020) The antiviral compound remdesivir potently inhibits RNA-dependent RNA polymerase from Middle East respiratory syndrome coronavirus. J Biol Chem 295(15):4773-4779. https://doi.org/10.1074/ jbc.AC120.013056

Grant WB, Lahore H, McDonnell SL, Baggerly CA, French CB, Aliano JL, Bhattoa HP (2020) Evidence that vitamin D supplementation could reduce risk of influenza and COVID-19 infections and deaths. Nutrients. https://doi.org/10.3390/nu12040988

Greenough TC, Babcock GJ, Roberts A, Hernandez HJ, Thomas WD Jr, Coccia JA, Graziano RF, Srinivasan M, Lowy I, Finberg RW, Subbarao K, Vogel L, Somasundaran M, Luzuriaga K, Sullivan JL, Ambrosino DM (2005) Development and characterization of a severe acute respiratory syndrome-associated coronavirusneutralizing human monoclonal antibody that provides effective immunoprophylaxis in mice. J Infect Dis 191(4):507-514. https ://doi.org/10.1086/427242

He J, Tao H, Yan Y, Huang SY, Xiao Y (2020) Molecular mechanism of evolution and human infection with SARS-CoV-2. Viruses. https://doi.org/10.3390/v12040428

Heurich A, Hofmann-Winkler H, Gierer S, Liepold T, Jahn O, Pohlmann S (2014) TMPRSS2 and ADAM17 cleave ACE2 differentially and only proteolysis by TMPRSS2 augments entry driven by the severe acute respiratory syndrome coronavirus spike protein. J Virol 88(2):1293-1307. https://doi.org/10.1128/JVI.02202 $-13$

Hoffmann M, Kleine-Weber H, Schroeder S, Kruger N, Herrler T, Erichsen S, Schiergens TS, Herrler G, Wu NH, Nitsche A, Muller MA, Drosten C, Pohlmann S (2020) SARS-CoV-2 cell entry depends on ACE2 and TMPRSS2 and is blocked by a clinically proven protease inhibitor. Cell 181(2):271-280 e278. https://doi. org/10.1016/j.cell.2020.02.052

Jan ter Meulen M, Alexander BH, Bakker P, Edward N, van den Brink P, Gerrit J, Weverling M, Byron EE, Martina P, Bart L, Haagmans P, Thijs KP, de Kruif PJ, Wolfgang PM, Willy Spaan P, Hans R, Gelderblom M, Jaap GM, Albert DME, Osterhaus P (2004) Human monoclonal antibody as prophylaxis for SARS coronavirus infection in ferrets. Lancet 363(9427):2139-2141

Jia X, Zhang P, Tian Y, Wang J, Zeng H, Wang J, Jiao L, Chen Z, Zhang L, He H, He K, Liu Y (2020) Clinical significance of IgM and IgG test for diagnosis of highly suspected COVID-19 infection. medRxiv. https://doi.org/10.1101/2020.02.28.20029025

Jiang Y, Guo D, Li C, Chen T, Li R (2020) High-resolution CT features of the COVID-19 infection in Nanchong City: initial and follow-up changes among different clinical types. Radiol Infect Dis. https://doi.org/10.1016/j.jrid.2020.05.001

Jin YH, Cai L, Cheng ZS, Cheng H, Deng T, Fan YP, Fang C, Huang D, Huang LQ, Huang Q, Han Y, Hu B, Hu F, Li BH, Li YR, Liang K, Lin LK, Luo LS, Ma J, Ma LL, Peng ZY, Pan YB, Pan ZY, Ren XQ, Sun HM, Wang Y, Wang YY, Weng H, Wei CJ, Wu DF, Xia J, Xiong Y, Xu HB, Yao XM, Yuan YF, Ye TS, Zhang XC, Zhang YW, Zhang YG, Zhang HM, Zhao Y, Zhao MJ, Zi H, Zeng XT, Wang XH (2020) A rapid advice guideline for the diagnosis and treatment of 2019 novel coronavirus
(2019-nCoV) infected pneumonia (standard version). Mil Med Res 7(1):4. https://doi.org/10.1186/s40779-020-0233-6

Joshi T, Sharma P, Mathpal S, Pundir H, Bhatt V, Chandra S (2020) In silico screening of natural compounds against COVID-19 by targeting Mpro and ACE2 using molecular docking. Eur Rev Med Pharmacol Sci 24(8):4529-4536. https://doi.org/10.26355 leurrev_202004_21036

Keicho N, Itoyama S, Kashiwase K, Phi NC, Long HT, Ha LD, Ban VV, Hoa BK, Hang NT, Hijikata M, Sakurada S, Satake M, Tokunaga K, Sasazuki T, Quy T (2009) Association of human leukocyte antigen class II alleles with severe acute respiratory syndrome in the Vietnamese population. Hum Immunol 70(7):527-531. https://doi.org/10.1016/j.humimm.2009.05.006

Kellner MJ, Koob JG, Gootenberg JS, Abudayyeh OO, Zhang F (2019) SHERLOCK: nucleic acid detection with CRISPR nucleases. Nat Protoc 14(10):2986-3012. https://doi. org/10.1038/s41596-019-0210-2

Kirchdoerfer RN, Cottrell CA, Wang N, Pallesen J, Yassine HM, Turner HL, Corbett KS, Graham BS, McLellan JS, Ward AB (2016) Pre-fusion structure of a human coronavirus spike protein. Nature 531(7592):118-121. https://doi.org/10.1038/natur e17200

Kuba K, Imai Y, Ohto-Nakanishi T, Penninger JM (2010) Trilogy of ACE2: a peptidase in the renin-angiotensin system, a SARS receptor, and a partner for amino acid transporters. Pharmacol Ther 128(1):119-128. https://doi.org/10.1016/j.pharmthera 2010.06.003

Kwok KO, Lai F, Wei WI, Wong SYS, Tang JWT (2020) Herd immunity-estimating the level required to halt the COVID-19 epidemics in affected countries. J Infect. https://doi.org/10.1016/j. jinf.2020.03.027

Li G, De Clercq E (2020) Therapeutic options for the 2019 novel coronavirus (2019-nCoV). Nat Rev Drug Discov 19(3):149-150. https://doi.org/10.1038/d41573-020-00016-0

Li T, Peng T (2013) Traditional Chinese herbal medicine as a source of molecules with antiviral activity. Antivir Res 97(1):1-9. https ://doi.org/10.1016/j.antiviral.2012.10.006

Li X, Geng M, Peng Y, Meng L, Lu S (2020) Molecular immune pathogenesis and diagnosis of COVID-19. J Pharm Anal 10(2):102108. https://doi.org/10.1016/j.jpha.2020.03.001

Li X, Wang L, Yan S, Yang F, Xiang L, Zhu J, Shen B, Gong Z (2020) Clinical characteristics of 25 death cases with COVID-19: a retrospective review of medical records in a single medical center, Wuhan, China. Int J Infect Dis. https://doi.org/10.1016/j. ijid.2020.03.053

Lip KM, Shen S, Yang X, Keng CT, Zhang A, Oh HL, Li ZH, Hwang LA, Chou CF, Fielding BC, Tan TH, Mayrhofer J, Falkner FG, Fu J, Lim SG, Hong W, Tan YJ (2006) Monoclonal antibodies targeting the HR2 domain and the region immediately upstream of the HR2 of the S protein neutralize in vitro infection of severe acute respiratory syndrome coronavirus. J Virol 80(2):941-950. https://doi.org/10.1128/JVI.80.2.941-950.2006

Liu J, Wu P, Gao F, Qi J, Kawana-Tachikawa A, Xie J, Vavricka CJ, Iwamoto A, Li T, Gao GF (2010) Novel immunodominant peptide presentation strategy: a featured HLA-A*2402-restricted cytotoxic T-lymphocyte epitope stabilized by intrachain hydrogen bonds from severe acute respiratory syndrome coronavirus nucleocapsid protein. J Virol 84(22):11849-11857. https://doi. org/10.1128/JVI.01464-10

Luk HKH, Li X, Fung J, Lau SKP, Woo PCY (2019) Molecular epidemiology, evolution and phylogeny of SARS coronavirus. Infect Genet Evolut 71:21-30. https://doi.org/10.1016/j.meegi d.2019.03.001

Mahase E (2020) Covid-19: WHO declares pandemic because of "alarming levels" of spread, severity, and inaction. BMJ 368:m1036. https://doi.org/10.1136/bmj.m1036

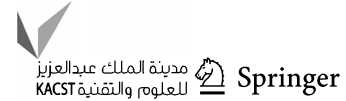


Malgie J, Schoones JW, Pijls BG (2020) Decreased mortality in COVID-19 patients treated with tocilizumab: a rapid systematic review and meta-analysis of observational studies. Clin Infect Dis. https://doi.org/10.1093/cid/ciaa1445

Martineau AR, Jolliffe DA, Hooper RL, Greenberg L, Aloia JF, Bergman P, Dubnov-Raz G, Esposito S, Ganmaa D, Ginde AA, Goodall EC, Grant CC, Griffiths CJ, Janssens W, Laaksi I, Manaseki-Holland S, Mauger D, Murdoch DR, Neale R, Rees JR, Simpson S Jr, Stelmach I, Kumar GT, Urashima M, Camargo CA Jr (2017) Vitamin D supplementation to prevent acute respiratory tract infections: systematic review and meta-analysis of individual participant data. BMJ 356:i6583. https://doi. org/10.1136/bmj. 6583

Martineau AR, Jolliffe DA, Greenberg L, Aloia JF, Bergman P, Dubnov-Raz G, Esposito S, Ganmaa D, Ginde AA, Goodall EC, Grant CC, Janssens W, Jensen ME, Kerley CP, Laaksi I, Manaseki-Holland S, Mauger D, Murdoch DR, Neale R, Rees JR, Simpson S, Stelmach I, Trilok Kumar G, Urashima M, Camargo CA, Griffiths CJ, Hooper RL (2019) Vitamin D supplementation to prevent acute respiratory infections: individual participant data meta-analysis. Health Technol Assess 23(2):1-44. https:// doi.org/10.3310/hta23020

Matrosovich M, Herrler G, Klenk HD (2015) Sialic acid receptors of viruses. Top Curr Chem 367:1-28. https://doi. org/10.1007/128_2013_466

Merad M, Martin JC (2020) Pathological inflammation in patients with COVID-19: a key role for monocytes and macrophages. Nat Rev Immunol 20(6):355-362. https://doi.org/10.1038/s4157 7-020-0331-4

Millet JK, Whittaker GR (2014) Host cell entry of Middle East respiratory syndrome coronavirus after two-step, furin-mediated activation of the spike protein. Proc Natl Acad Sci USA 111(42):15214-15219. https://doi.org/10.1073/pnas.1407087111

Million M, Gautret P, Colson P, Roussel Y, Dubourg G, Chabriere E, Honore S, Rolain JM, Fenollar F, Fournier PE, Lagier JC, Parola P, Brouqui P, Raoult D (2020) Clinical efficacy of chloroquine derivatives in COVID-19 infection: comparative meta-analysis between the big data and the real world. New Microbes New Infect 38:100709. https://doi.org/10.1016/j.nmni.2020.100709

Mohamed E-T, Haim HB, Jinzhao S (2020) A single and two-stage, closed-tube, molecular test for the 2019 novel Coronavirus (COVID-19) at home, clinic, and points of entry. ChemRxiv. https://doi.org/10.26434/chemrxiv.11860137.v1

Monsen ER (2000) Dietary reference intakes for the antioxidant nutrients: vitamin C, vitamin E, selenium, and carotenoids. J Am Diet Assoc 100(6):637-640. https://doi.org/10.1016/S0002 $-8223(00) 00189-9$

Ng OW, Keng CT, Leung CS, Peiris JS, Poon LL, Tan YJ (2014) Substitution at aspartic acid 1128 in the SARS coronavirus spike glycoprotein mediates escape from a S2 domain-targeting neutralizing monoclonal antibody. PLoS ONE 9(7):e102415. https ://doi.org/10.1371/journal.pone.0102415

Omar S, Ismail B, Bouslama Z, Djemel A (2020) In-silico identification of potent inhibitors of COVID-19 main protease (Mpro) and angiotensin converting enzyme 2 (ACE2) from natural products: quercetin, hispidulin, and cirsimaritin exhibited better potential inhibition than hydroxy-chloroquine against COVID19 main protease active site and ACE2. ChemRxiv. https://doi. org/10.26434/chemrxiv.12181404.v1

Ou X, Liu Y, Lei X, Li P, Mi D, Ren L, Guo L, Guo R, Chen T, Hu J, Xiang Z, Mu Z, Chen X, Chen J, Hu K, Jin Q, Wang J, Qian Z (2020) Characterization of spike glycoprotein of SARS-CoV-2 on virus entry and its immune cross-reactivity with SARS-CoV. Nat Commun 11(1):1620. https://doi.org/10.1038/s41467-02015562-9
Pal M, Berhanu G, Desalegn C, Kandi V (2020) Severe acute respiratory syndrome coronavirus-2 (SARS-CoV-2): an update. Cureus 12(3):e7423-e7423. https://doi.org/10.7759/cureus.7423

Pan Y, Guan H, Zhou S, Wang Y, Li Q, Zhu T, Hu Q, Xia L (2020) Initial CT findings and temporal changes in patients with the novel coronavirus pneumonia (2019-nCoV): a study of 63 patients in Wuhan, China. Eur Radiol. https://doi.org/10.1007/s00330-02006731-x

Pan Y, Guan H, Zhou S, Wang Y, Li Q, Zhu T, Hu Q, Xia L (2020) Initial CT findings and temporal changes in patients with the novel coronavirus pneumonia (2019-nCoV): a study of 63 patients in Wuhan, China. Eur Radiol 30(6):3306-3309. https:// doi.org/10.1007/s00330-020-06731-x

Pathak DSK, Salunke DAA, Thivari DP, Pandey A, Nandy DK, Harish VKRD, Pandey DS, Chawla DJ, Mujawar DJ, Dhanwate DA, Menon DV (2020) No benefit of hydroxychloroquine in COVID19: results of systematic review and meta-analysis of randomized controlled trials. Diabetes Metab Syndr 14(6):1673-1680. https ://doi.org/10.1016/j.dsx.2020.08.033

Perlman S, Netland J (2009) Coronaviruses post-SARS: update on replication and pathogenesis. Nat Rev Microbiol 7(6):439-450. https ://doi.org/10.1038/nrmicro2147

Rabi FA, Al Zoubi MS, Kasasbeh GA, Salameh DM, Al-Nasser AD (2020) SARS-CoV-2 and Coronavirus disease 2019: what we know so far. Pathogens (Basel, Switzerland). https://doi. org/10.3390/pathogens9030231

Rajendran K, Krishnasamy N, Rangarajan J, Rathinam J, Natarajan M, Ramachandran A (2020) Convalescent plasma transfusion for the treatment of COVID-19: systematic review. J Med Virol. https:// doi.org/10.1002/jmv.25961

Ratre YK, Vishvakarma NK, Bhaskar LVKS, Verma HK (2020) Dynamic propagation and impact of pandemic influenza A (2009 H1N1) in children: a detailed review. Curr Microbiol. https://doi. org/10.1007/s00284-020-02213-x

Rejnmark L, Bislev LS, Cashman KD, Eiriksdottir G, Gaksch M, Grubler M, Grimnes G, Gudnason V, Lips P, Pilz S, van Schoor NM, Kiely M, Jorde R (2017) Non-skeletal health effects of vitamin D supplementation: a systematic review on findings from meta-analyses summarizing trial data. PLoS ONE 12(7):e0180512. https://doi.org/10.1371/journal.pone.0180512

Rohollah V, Baradaran A, Mirzazadeh A, Bhaskar LV (2020) Coronavirus-nephropathy; renal involvement in COVID-19. J Renal Inj Prev 9(2):e18

Rondanelli M, Miccono A, Lamburghini S, Avanzato I, Riva A, Allegrini P, Faliva MA, Peroni G, Nichetti M, Perna S (2018) Self-care for common colds: the pivotal role of Vitamin D, Vitamin C, zinc, and echinacea in three main immune interactive clusters (physical barriers, innate and adaptive immunity) involved during an episode of common colds-practical advice on dosages and on the time to take these nutrients/botanicals in order to prevent or treat common colds. Evid Based Complement Altern Med eCAM 2018:5813095. https://doi. org/10.1155/2018/5813095

Sarma P, Shekhar N, Prajapat M, Avti P, Kaur H, Kumar S, Singh S, Kumar H, Prakash A, Dhibar DP, Medhi B (2020) In-silico homology assisted identification of inhibitor of RNA binding against 2019-nCoV N-protein ( $\mathrm{N}$ terminal domain). J Biomol Struct Dyn. https://doi.org/10.1080/07391102.2020.1753580

Shanmugaraj B, Siriwattananon K, Wangkanont K, Phoolcharoen W (2020) Perspectives on monoclonal antibody therapy as potential therapeutic intervention for Coronavirus disease-19 (COVID19). Asian Pac J Allergy Immunol 38(1):10-18. https://doi. org/10.12932/ap-200220-0773

Shen M, Zhou Y, Ye J, Abdullah Al-Maskri AA, Kang Y, Zeng S, Cai S (2020) Recent advances and perspectives of nucleic 
acid detection for coronavirus. J Pharm Anal. https://doi. org/10.1016/j.jpha.2020.02.010

Shen K, Yang Y, Wang T, Zhao D, Jiang Y, Jin R, Zheng Y, Xu B, Xie Z, Lin L, Shang Y, Lu X, Shu S, Bai Y, Deng J, Lu M, Ye L, Wang X, Wang Y, Gao L (2020) Diagnosis, treatment, and prevention of 2019 novel coronavirus infection in children: experts' consensus statement. World J Pediatr. https://doi.org/10.1007/ s12519-020-00343-7

Shereen MA, Khan S, Kazmi A, Bashir N, Siddique R (2020) COVID19 infection: origin, transmission, and characteristics of human coronaviruses. J Adv Res 24:91-98. https://doi.org/10.1016/j. jare.2020.03.005

Siemieniuk RA, Bartoszko JJ, Ge L, Zeraatkar D, Izcovich A, Kum E, Pardo-Hernandez H, Rochwerg B, Lamontagne F, Han MA, Liu Q, Agarwal A, Agoritsas T, Chu DK, Couban R, Darzi A, Devji T, Fang B, Fang C, Flottorp SA, Foroutan F, Heels-Ansdell D, Honarmand K, Hou L, Hou X, Ibrahim Q, Loeb M, Marcucci M, McLeod SL, Motaghi S, Murthy S, Mustafa RA, Neary JD, Qasim A, Rada G, Riaz IB, Sadeghirad B, Sekercioglu N, Sheng L, Sreekanta A, Switzer C, Tendal B, Thabane L, Tomlinson G, Turner T, Vandvik PO, Vernooij RW, Viteri-Garcia A, Wang Y, Yao L, Ye Z, Guyatt GH, Brignardello-Petersen R (2020) Drug treatments for covid-19: living systematic review and network meta-analysis. BMJ 370:m2980. https://doi.org/10.1136/bmj. $\mathrm{m} 2980$

Simmons G, Reeves JD, Rennekamp AJ, Amberg SM, Piefer AJ, Bates $P$ (2004) Characterization of severe acute respiratory syndromeassociated coronavirus (SARS-CoV) spike glycoprotein-mediated viral entry. Proc Natl Acad Sci USA 101(12):4240-4245. https://doi.org/10.1073/pnas.0306446101

Snijder EJ, Bredenbeek PJ, Dobbe JC, Thiel V, Ziebuhr J, Poon LL, Guan Y, Rozanov M, Spaan WJ, Gorbalenya AE (2003) Unique and conserved features of genome and proteome of SARS-coronavirus, an early split-off from the coronavirus group 2 lineage. J Mol Biol 331(5):991-1004. https://doi.org/10.1016/s0022 -2836(03)00865-9

Snijder EJ, van der Meer Y, Zevenhoven-Dobbe J, Onderwater JJ, van der Meulen J, Koerten HK, Mommaas AM (2006) Ultrastructure and origin of membrane vesicles associated with the severe acute respiratory syndrome coronavirus replication complex. J Virol 80(12):5927-5940. https://doi.org/10.1128/JVI.02501-05

Struck AW, Axmann M, Pfefferle S, Drosten C, Meyer B (2012) A hexapeptide of the receptor-binding domain of SARS coronavirus spike protein blocks viral entry into host cells via the human receptor ACE2. Antivir Res 94(3):288-296. https://doi. org/10.1016/j.antiviral.2011.12.012

Sui J, Li W, Murakami A, Tamin A, Matthews LJ, Wong SK, Moore MJ, Tallarico AS, Olurinde M, Choe H, Anderson LJ, Bellini WJ, Farzan M, Marasco WA (2004) Potent neutralization of severe acute respiratory syndrome (SARS) coronavirus by a human $\mathrm{mAb}$ to $\mathrm{S} 1$ protein that blocks receptor association. Proc Natl Acad Sci USA 101(8):2536-2541. https://doi.org/10.1073/ pnas.0307140101

Tang W, Cao Z, Han M, Wang Z, Chen J, Sun W, Wu Y, Xiao W, Liu S, Chen E, Chen W, Wang X, Yang J, Lin J, Zhao Q, Yan Y, Xie Z, Li D, Yang Y, Liu L, Qu J, Ning G, Shi G, Xie Q (2020) Hydroxychloroquine in patients with mainly mild to moderate coronavirus disease 2019: open label, randomised controlled trial. BMJ 369:m1849. https://doi.org/10.1136/bmj.m1849

Taubenberger JK, Morens DM (2006) 1918 Influenza: the mother of all pandemics. Emerg Infect Dis 12(1):15-22. https://doi. org/10.3201/eid1201.050979

ter Meulen J, van den Brink EN, Poon LL, Marissen WE, Leung CS, Cox F, Cheung CY, Bakker AQ, Bogaards JA, van Deventer E, Preiser W, Doerr HW, Chow VT, de Kruif J, Peiris JS, Goudsmit J (2006) Human monoclonal antibody combination against SARS coronavirus: synergy and coverage of escape mutants. PLoS Med 3(7):e237. https://doi.org/10.1371/journal.pmed.0030237

Tu X, Chong WP, Zhai Y, Zhang H, Zhang F, Wang S, Liu W, Wei M, Siu NH, Yang H, Yang W, Cao W, Lau YL, He F, Zhou G (2015) Functional polymorphisms of the CCL2 and MBL genes cumulatively increase susceptibility to severe acute respiratory syndrome coronavirus infection. J Infect 71(1):101-109. https:// doi.org/10.1016/j.jinf.2015.03.006

van den Brink EN, Ter Meulen J, Cox F, Jongeneelen MA, Thijsse A, Throsby M, Marissen WE, Rood PM, Bakker AB, Gelderblom HR, Martina BE, Osterhaus AD, Preiser W, Doerr HW, de Kruif J, Goudsmit J (2005) Molecular and biological characterization of human monoclonal antibodies binding to the spike and nucleocapsid proteins of severe acute respiratory syndrome coronavirus. J Virol 79(3):1635-1644. https://doi.org/10.1128/ JVI.79.3.1635-1644.2005

Verma HK, Merchant N, Verma MK, Kuru CI, Singh AN, Ulucan F, Verma P, Bhattacharya A, Bhaskar L (2020) Current updates on the European and WHO registered clinical trials of coronavirus disease 2019 (COVID-19). Biomedical journal 43(5):424-433. https://doi.org/10.1016/j.bj.2020.07.008

Verma HK, Farran B, Bhaskar LVKS (2020) Convalescent plasma transfusion a promising therapy for coronavirus diseases 2019 (COVID-19): current updates. Antibody Ther. https://doi. org/10.1093/abt/tbaa010

Walls AC, Xiong X, Park YJ, Tortorici MA, Snijder J, Quispe J, Cameroni E, Gopal R, Dai M, Lanzavecchia A, Zambon M, Rey FA, Corti D, Veesler D (2019) Unexpected receptor functional mimicry elucidates activation of coronavirus fusion. Cell 176(5):1026-10391015. https://doi.org/10.1016/j. cell.2018.12.028

Wang SF, Chen KH, Chen M, Li WY, Chen YJ, Tsao CH, Yen MY, Huang JC, Chen YM (2011) Human-leukocyte antigen class I $\mathrm{Cw} 1502$ and class II DR 0301 genotypes are associated with resistance to severe acute respiratory syndrome (SARS) infection. Viral Immunol 24(5):421-426. https://doi.org/10.1089/ vim.2011.0024

Williams AE, Chambers RC (2014) The mercurial nature of neutrophils: still an enigma in ARDS? Am J Physiol Lung Cell Mol Physiol 306(3):L217-230. https://doi.org/10.1152/ajplung.00311 .2013

Wu D, Meydani SN (2014) Age-associated changes in immune function: impact of vitamin $\mathrm{E}$ intervention and the underlying mechanisms. Endocr Metab Immune Disord Drug Targets 14(4):283289. https://doi.org/10.2174/1871530314666140922143950

Xia S, Liu M, Wang C, Xu W, Lan Q, Feng S, Qi F, Bao L, Du L, Liu S, Qin C, Sun F, Shi Z, Zhu Y, Jiang S, Lu L (2020) Inhibition of SARS-CoV-2 (previously 2019-nCoV) infection by a highly potent pan-coronavirus fusion inhibitor targeting its spike protein that harbors a high capacity to mediate membrane fusion. Cell Res 30(4):343-355. https://doi.org/10.1038/s41422-020-0305-x

Xiao C, Li X, Liu S, Sang Y, Gao S-J, Gao F (2020) HIV-1 did not contribute to the 2019-nCoV genome. Emerg Microbes Infect 9(1):378-381. https://doi.org/10.1080/22221751.2020.1727299

Xie X, Zhong Z, Zhao W, Zheng C, Wang F, Liu J (2020) Chest CT for typical 2019-nCoV pneumonia: relationship to negative RT-PCR Testing. Radiology. https://doi.org/10.1148/radiol.2020200343

Xie J, Tong Z, Guan X, Du B, Qiu H (2020) Clinical characteristics of patients who died of Coronavirus Disease 2019 in China. JAMA Netw Open 3(4):e205619. https://doi.org/10.1001/jamanetwor kopen.2020.5619

Xu Z, Shi L, Wang Y, Zhang J, Huang L, Zhang C, Liu S, Zhao P, Liu H, Zhu L, Tai Y, Bai C, Gao T, Song J, Xia P, Dong J, Zhao J, Wang FS (2020) Pathological findings of COVID-19 associated with acute respiratory distress syndrome. Lancet Respir Med 8(4):420-422. https://doi.org/10.1016/S2213-2600(20)30076-X

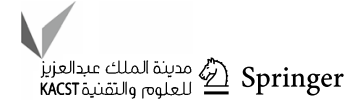


Xu X, Chen P, Wang J, Feng J, Zhou H, Li X, Zhong W, Hao P (2020) Evolution of the novel coronavirus from the ongoing Wuhan outbreak and modeling of its spike protein for risk of human transmission. Sci China Life Sci 63(3):457-460. https://doi. org/10.1007/s11427-020-1637-5

Yahi N, Fantini J (2014) Deciphering the glycolipid code of Alzheimer's and Parkinson's amyloid proteins allowed the creation of a universal ganglioside-binding peptide. PLoS ONE 9(8):e104751. https://doi.org/10.1371/journal.pone.0104751

Yamamoto N, Yang R, Yoshinaka Y, Amari S, Nakano T, Cinatl J, Rabenau H, Doerr HW, Hunsmann G, Otaka A, Tamamura H, Fujii N (2004) HIV protease inhibitor nelfinavir inhibits replication of SARS-associated coronavirus. Biochem Biophys Res Commun 318(3):719-725. https://doi.org/10.1016/j. bbrc. 2004.04.083

Yu F, Du L, Ojcius DM, Pan C, Jiang S (2020) Measures for diagnosing and treating infections by a novel coronavirus responsible for a pneumonia outbreak originating in Wuhan, China. Microbes Infect 22(2):74-79. https://doi.org/10.1016/j.micinf.2020.01.003

Yu L, Wu S, Hao X, Li X, Liu X, Ye S, Han H, Dong X, Li X, Li J, Liu J, Liu N, Zhang W, Pelechano V, Chen W-H, Yin X (2020b) Rapid colorimetric detection of COVID-19 coronavirus using a reverse tran-scriptional loop-mediated isothermal amplification (RT-LAMP) diagnostic plat-form: iLACO. medRxiv. https://doi. org/10.1101/2020.02.20.20025874

Yuan P, Ai P, Liu Y, Ai Z, Wang Y, Cao W, Xia X, Zheng JC (2020) Safety, tolerability, and immunogenicity of COVID-19 vaccines: a systematic review and meta-analysis. medRxiv. https://doi. org/10.1101/2020.11.03.20224998

Zhai P, Ding Y, Wu X, Long J, Zhong Y, Li Y (2020) The epidemiology, diagnosis and treatment of COVID-19. Int J Antimicrob Agents. https://doi.org/10.1016/j.ijantimicag.2020.105955

Zhang DH, Wu KL, Zhang X, Deng SQ, Peng B (2020) In silico screening of Chinese herbal medicines with the potential to directly inhibit 2019 novel coronavirus. J Integr Med 18(2):152-158. https://doi.org/10.1016/j.joim.2020.02.005

Zhang Y, Odiwuor N, Xiong J, Sun L, Nyaruaba RO, Wei H, Tanner NA (2020b) Rapid molecular detection of SARS-CoV-2 (COVID-19) virus RNA using colorimetric LAMP. medRxiv. https://doi.org/10.1101/2020.02.26.20028373

Zhou P, Yang XL, Wang XG, Hu B, Zhang L, Zhang W, Si HR, Zhu Y, Li B, Huang CL, Chen HD, Chen J, Luo Y, Guo H, Jiang RD, Liu MQ, Chen Y, Shen XR, Wang X, Zheng XS, Zhao K, Chen QJ, Deng F, Liu LL, Yan B, Zhan FX, Wang YY, Xiao GF, Shi ZL (2020) A pneumonia outbreak associated with a new coronavirus of probable bat origin. Nature 579(7798):270-273. https://doi. org/10.1038/s41586-020-2012-7

Zhu Z, Chakraborti S, He Y, Roberts A, Sheahan T, Xiao X, Hensley LE, Prabakaran P, Rockx B, Sidorov IA, Corti D, Vogel L, Feng Y, Kim JO, Wang LF, Baric R, Lanzavecchia A, Curtis KM, Nabel GJ, Subbarao K, Jiang S, Dimitrov DS (2007) Potent cross-reactive neutralization of SARS coronavirus isolates by human monoclonal antibodies. Proc Natl Acad Sci USA 104(29):12123-12128. https://doi.org/10.1073/pnas.0701000104 